\title{
THE FEMALE SECONDARY STIPEND AND ASSISTANCE PROGRAM IN BANGLADESH WHAT DID IT ACCOMPLISH?
}

Shahidur Rahman Khandker, Hussain Akhterus Samad, Nobuhiko Fuwa, and Ryotaro Hayashi

NO. 81

January 2021

\section{ADB SOUTH ASIA WORKING PAPER SERIES}





\section{ADB South Asia Working Paper Series}

\section{The Female Secondary Stipend and Assistance Program in Bangladesh: What Did It Accomplish?}

Shahidur Rahman Khandker, Hussain Akhterus Samad, Nobuhiko Fuwa, and Ryotaro Hayashi

No. 81 | January 2021
Shahidur Rahman Khandker is a former Lead Economist in the Development Research Group of the World Bank; Hussain Samad is a Consultant in the Asian Development Bank (ADB); Nobuhiko Fuwa was a Professor in the Graduate School of Public Policy of the University of Tokyo; and Ryotaro Hayashi is a Social Sector Economist, Human and Social Development Division, South Asia Department, ADB. The authors are grateful to Yasuyuki Sawada, Sungsup Ra, Takashi Yamano, Amir Hamza Jilani, Eisuke Tajima, Brenda Batistiana, Francesco Tornieri, and participants of the ADB Economists' Forum and Bangladesh Institute for Development Studies workshop in 2019 as well as KDIS-3ie-ADB-ADBI Conference on Impact Evaluation - Challenges and Promise for Human Capital Development in Asia in 2020 for their feedback and comments. The authors would also like to thank Kazi Zahidul Huq for providing excellent support in managing the 2018 survey and data cleaning. Financial support from the University of Tokyo Graduate School of Public Policy for data collection is gratefully acknowledged. 
(C) 2021 Asian Development Bank

6 ADB Avenue, Mandaluyong City, 1550 Metro Manila, Philippines

Tel +632 8632 4444; Fax +63286362444

www.adb.org

Some rights reserved. Published in 2021.

Printed in the Philippines

ISSN 2313-5867 (print), 2313-5875 (electronic)

Publication Stock No. WPS210021-2

DOI: http://dx.doi.org/10.22617/WPS210021-2

The views expressed in this publication are those of the authors and do not necessarily reflect the views and policies of the Asian Development Bank (ADB) or its Board of Governors or the governments they represent.

ADB does not guarantee the accuracy of the data included in this publication and accepts no responsibility for any consequence of their use. The mention of specific companies or products of manufacturers does not imply that they are endorsed or recommended by ADB in preference to others of a similar nature that are not mentioned.

By making any designation of or reference to a particular territory or geographic area, or by using the term "country" in this document, $A D B$ does not intend to make any judgments as to the legal or other status of any territory or area.

This work is available under the Creative Commons Attribution 3.0 IGO license (CC BY 3.0 IGO) https://creativecommons.org/licenses/by/3.0/igo/. By using the content of this publication, you agree to be bound by the terms of this license. For attribution, translations, adaptations, and permissions, please read the provisions and terms of use at https://www.adb.org/terms-use\#openaccess.

This CC license does not apply to non-ADB copyright materials in this publication. If the material is attributed to another source, please contact the copyright owner or publisher of that source for permission to reproduce it. ADB cannot be held liable for any claims that arise as a result of your use of the material.

Please contact pubsmarketing@adb.org if you have questions or comments with respect to content, or if you wish to obtain copyright permission for your intended use that does not fall within these terms, or for permission to use the ADB logo.

The ADB South Asia Working Paper Series is a forum for ongoing and recently completed research and policy studies undertaken in $A D B$ or on its behalf. It is meant to enhance greater understanding of current important economic and development issues in South Asia, promote policy dialogue among stakeholders, and facilitate reforms and development management.

The ADB South Asia Working Paper Series is a quick-disseminating, informal publication whose titles could subsequently be revised for publication as articles in professional journals or chapters in books. The series is maintained by the South Asia Department. The series will be made available on the ADB website and on hard copy.

Corrigenda to ADB publications may be found at http://www.adb.org/publications/corrigenda.

Note:

In this publication, "\$” refers to United States dollars. 


\section{CONTENTS}

TABLES, FIGURES, AND BOX

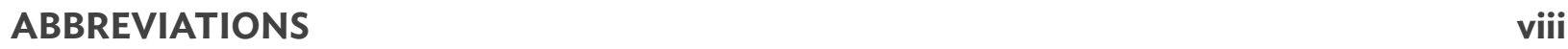

$\begin{array}{ll}\text { ABSTRACT } & \text { ix }\end{array}$

$\begin{array}{ll}\text { I. INTRODUCTION } & 1\end{array}$

II. SIGNIFICANCE OF THE STUDY 4

A. What Do We Already Know?

B. Value-Added of the Longitudinal Impact Study 6

$\begin{array}{ll}\text { III. } & \text { DATA AND ITS MAJOR CHARACTERISTICS }\end{array}$

A. Description of Data 7

B. Descriptive Statistics of Outcome Variables 9

$\begin{array}{lr}\text { IV. ESTIMATION STRATEGY } & 14\end{array}$

A. Intent-to-Treat Effects 15

B. Treatment-on-the-Treated Effects

C. Data Issues Relevant to Estimation 18

$\begin{array}{lr}\text { V. FINDINGS } & 20\end{array}$

A. Intent-to-Treat Effects 20

B. Treatment-on-the-Treated Effects $\quad 28$

C. Income Effects of Female Education 34

$\begin{array}{ll}\text { VI. CONCLUSIONS } & 36\end{array}$

APPENDIX: EVOLUTION OF THE FEMALE SECONDARY STIPEND 40

AND ASSISTANCE PROGRAM

$\begin{array}{lr}\text { REFERENCES } & \mathbf{5 0}\end{array}$ 


\section{TABLES, FIGURES, AND BOX}

\section{TABLE}

1 Female Secondary Stipend and Assistance Program-Descriptive Statistics of Education Outcomes by Stipend Eligibility: Girls

2 Female Secondary Stipend and Assistance Program-Descriptive Statistics of Employment and Spouse-Related Outcomes by Stipend Eligibility: Girls

6 Female Secondary Stipend and Assistance Program-Intent-to-Treat Effects on Women's Employment and Their Husbands' Outcomes

7 Female Secondary Stipend and Assistance Program-Intent-to-Treat Effects on Women's Marital and Fertility-Related Outcomes

8 Female Secondary Stipend and Assistance Program-Intent-to-Treat Effects on Education Outcomes: Boys

9 Female Secondary Stipend and Assistance Program-Treatment-on-the-Treated Effects on Women's Education Outcomes

10 Female Secondary Stipend and Assistance Program-Treatment-on-the-Treated Effects on Employment and Spouse-Related Outcomes

11 Female Secondary Stipend and Assistance Program-Treatment-on-the-Treated Effects on Marriage and Fertility-Related Outcomes

12 Female Secondary Stipend and Assistance Program-Treatment-on-the-Treated Effects on Education Outcomes: Boys

13 Female Secondary Stipend and Assistance Program-Treatment-on-the-Treated Effects of Participation Duration (Years) on Education Outcomes

14 Female Secondary Stipend and Assistance Program - Treatment-on-the-Treated Effects of Participation Duration (Years) on Women's Employment and Husband's Outcomes

15 Female Secondary Stipend and Assistance Program - Treatment-on-the-Treated Effects of Participation Duration (Years) on Marriage and Fertility-Related Outcomes

16 Female Secondary Stipend and Assistance Program - Treatment-on-the-Treated Effects of Participation Duration (Years) on Boys' Education Outcomes

17 Female Secondary Stipend and Assistance Program-Income Effects of Education and the Program 
A1.1 Rates of Various Stipend Programs, 2017 (Taka)

A1.2 Female Secondary Stipend and Assistance Program-Salient Characteristics

of the Target Sample (ages 0-20 in 1991/92)

A1.3 Female Secondary Stipend and Assistance Program-Baseline Characteristics by Individual Attrition

A1.4 Female Secondary Stipend and Assistance Program-Baseline Determinants of Individual Attrition (probit estimates)

A1.5 Female Secondary Stipend and Assistance Program-Baseline Characteristics by FSSAP Eligibility

A1.6 Female Secondary Stipend and Assistance Program-Descriptive Statistics of Selected Explanatory Variables

A1.7 Female Secondary Stipend and Assistance Program-Descriptive Statistics of Women's Outcome Variables

A1.8 Female Secondary Stipend and Assistance Program-Effects on Girls' Education Outcomes, Using a Third Cohort, Randomly Selected from the Control Group, as an Additional Regressor

A1.9 Female Secondary Stipend and Assistance Program—First Stage Regression Output for Estimation: Determinants of Girls' Participation

\section{FIGURE}

1 Secondary Enrollment-Distribution of Boys and Girls

2 Mean Age at Marriage of Females

3 Grade Attainment by Survey Years

\section{BOX}




\section{ABBREVIATIONS}

$\begin{array}{lll}\text { ADB } & - & \text { Asian Development Bank } \\ \text { COVID-19 } & - & \text { coronavirus disease } \\ \text { DID } & - & \text { difference-in-differences } \\ \text { FSSAP } & - & \text { Female Secondary Stipend and Assistance Program } \\ \text { FE-IV } & - & \text { fixed effects instrumental variable } \\ \text { ITT } & - & \text { intent-to-treat } \\ \text { TOT } & - & \text { Treatment-on-the-Treated }\end{array}$




\begin{abstract}
The Government of Bangladesh introduced the Female Secondary Stipend and Assistance Program (FSSAP) in 1994 with the support of development partners, including the Asian Development Bank, to increase female secondary school enrollment and completion, as well as discourage early marriage. The study, using longitudinal data at the household and individual level over 26 years, and based on with-and-without and before-and-after comparison (i.e., the difference-in-differences method), examines a range of outcomes of interest. Impact evaluation estimates suggest that FSSAP improved education outcomes in the short run, including boys' education outcomes through sibling spillover effects. In the long term, FSSAP was successful in delaying marriage, increasing the probability of self-employment and nonfarm employment among employed women, and increasing the probability of marrying men who are more educated and employed more in the nonfarm sector than those married to the control group women. The program was also successful in enhancing contraceptive use, reducing fertility, and increasing preference for daughters. A conservative estimate shows that the development benefits of the stipend program outweigh its cost by more than $200 \%$. The estimates of high returns to secondary education of women thus not only justify the investment but also present a win-win situation for families and society at large. The impact of FSSAP identified through this paper is higher than that in the existing literature on FSSAP, which has policy implications and relevance during this COVID-19 pandemic period and beyond.
\end{abstract}





\section{INTRODUCTION}

1. Gender disparity in adult literacy, school enrollment, and attainment was widespread in the early 1990s in developing countries, particularly in Africa, the Middle East, and South Asia. Although this disparity has existed for all ages, it was more pronounced at the secondary than the primary level of schooling (Herz et al. 1991).

2. Bangladesh was not atypical. The adult literacy rate for women was only $26 \%$ in 1991 , compared to $44 \%$ for men. But the situation has improved over time: in 2001, the adult literacy rate was $41 \%$ among women and $54 \%$ among men. ${ }^{1}$ In addition, gender disparity in school enrollment, in particular at the secondary level, has substantially declined or reversed in recent years: in 1998, enrollment was $43 \%$ for males and $41 \%$ for females at the secondary level. Those figures improved to $61 \%$ (male) and $72 \%$ (female) in 2018. ${ }^{2}$

3. Gender disparities in schooling persist in many societies even though economic returns to education are higher for women than for men (King and Hill 1993, Schultz 1987, Psacharopoulos and Patrinos 2018). Cost is a primary factor underlying the gaps in schooling. Educating girls is more costly than educating boys in many developing countries (Herz et al. 1991, Mannan 1988). Cultural practices also dictate that parents pay more for clothing and transportation for girls than for boys. Gender disparity is an inferior good, becoming less pronounced as income rises (Herz et al. 1991, King and Hill 1993, Schultz 1987). However, it would take many years for income growth to greatly reduce gender disparity.

4. Many factors, beyond equity concerns, induce governments to subsidize girls' schooling. Increased educational attainment for girls has been shown to be strongly associated with delayed marriage and reduced fertility (Currie and Moretti 2003, Breierova and Duflo 2004), and positive intergenerational spillovers through greater human capital investments in children (Strauss and Thomas 1995). Effects are more pronounced for secondary than primary education.

5. Not surprisingly, some developing countries have introduced school-level interventions to promote the schooling of girls through the provision of subsidies. In Pakistan, a female fellowship program for primary school was found to increase school enrollment of both girls and boys (Kim, Alderman, and Orazem 1999). In Colombia, school voucher programs targeted to girls were found to increase enrollment rates of both girls and boys (King, Orazem, and Wohlgemuth 1999).

6. The Government of Bangladesh introduced the Female Secondary Stipend and Assistance Program (FSSAP) in the early 1990 s. $^{3}$ More specifically, in 1994, the government sought to increase rural female enrollment at the secondary school level by launching four female secondary stipend projects under the FSSAP, funded by the International Development Association (118 thanas or districts); the Female Secondary Stipend Project, funded by the government (282 thanas); the Secondary Education Development Project, funded by the Asian Development Bank (ADB) (53 thanas);

World Bank. Literacy Rate, Adult Male (\% of males ages 15 and above) - Bangladesh. https://data.worldbank.org/indicator/ SE.ADT.LITR.FE.ZS?locations=BD (accessed 31 July 2020).

2 World Bank. School Enrollment, Secondary, Male (\% net). https://data.worldbank.org/indicator/SE.SEC.NENR. FE? locations=BD (accessed 31 July 2020).

3 The Appendix summarizes the historical evolution of the FSSAP into four different phases: (i) 1982-1994, (ii) 1994-2008, (iii) 2008-2018, and (iv) 2018-2023. 
and the Female Secondary Education Project, funded by Norwegian Agency for Development Cooperation (7 thanas). These projects introduced a similar nationwide stipend program targeted to girls in grades 6 through 10 in 460 rural thanas starting in 1994. ${ }^{4}$

7. The FSSAP is a conditional cash transfer program. It introduced a uniform stipend and tuition subsidy program for each girl attending a secondary school in rural areas who satisfied the following eligibility criteria: (i) attended $75 \%$ of school days, (ii) attained some level of measured academic proficiency ( $45 \%$ in class-level test scores), and (iii) remained unmarried until completion of secondary school certificate examination. ${ }^{5}$ Once a school has participated in the program, all female students satisfying these criteria could receive a specified stipend amount and other allowances as prescribed for each grade, and cash is transferred directly to a bank account in the name of girls who attended school.

8. The stipend was provided based on eligible grades, rather than age, but had some variations, since girls from some households did not wish to receive stipends because they were wealthy, and also due to religious reasons. The combined stipend and tuition subsidy for each girl was taka (Tk) 906 for nongovernment schools and Tk847 for government schools. The stipend itself accounted for two-thirds of the total outlay used to support the program. ${ }^{6}$

9. The female subsidy was about $6 \%$ of Bangladesh's per capita income. This program supported over 2 million girls each year. In its first phase, the cost of FSSAP during the academic years of 1994-1999 was $\$ 71$ million, which was 1.3\% of the education budget (Liang 1996).

10. Various reports, including those from ADB and the World Bank's operational documents related to FSSAP, point to the success of the FSSAP in reducing gender disparity in secondary education (World Bank 1997, ADB 2006). Secondary school enrollment among girls has increased markedly in recent years. Aggregate statistics suggest that girls' school enrollment has increased at a rate of $13 \%$ per year since 1994 , while the rate for boys has only been $2.5 \%$ per year. ${ }^{7}$ Consequently, among the total enrollees, girls' share exceeded boys' (Figure 1).

11. In fact, both school enrollment and attainment of the secondary-level girls exceeded that of boys in the years following the introduction of the stipend. In addition, women's age at first marriage has risen by a full year since FSSAP was introduced (Figure 2). This means that the program was well targeted and it achieved its stated goals. The stipend program continued to evolve throughout the four stages of the FSSAP (see Appendix), with a final stage of Harmonized Stipend Program to be implemented from 2018 to 2023.

12. The objectives of the FSSAP program were to (i) increase school enrollment among secondary-schooled girls, (ii) improve the secondary schooling completion rate for girls, and (iii) delay age at marriage for females.

4 Bangladesh's school system consists of three levels: primary school (grades 1-5), secondary school (grades 6-10), and higher secondary school (grades 11-12). The next level is a 4-year college or university education. The female stipend program was introduced for girls in rural areas starting in 1994 at the secondary school level (grades 6-10). This paper terms the four different secondary school level projects for girls as Female Secondary Stipend and Assistance Program (FSSAP) and evaluates its effectiveness in achieving the stated objectives of the program supported by government and other development partners.

5 The secondary school certificate examination means passing grade 10 level examination, which is managed by the secondary school board, not by the school.

6 In 1994, the annual stipends were equivalent to $\$ 18$ in grade $6, \$ 20$ in grade $7, \$ 22$ in grade $8, \$ 36$ in grade 9 , and $\$ 45$ in grade 10 .

7 In addition, the proportion of girls marrying at an early age has declined markedly. 
Figure 1: Secondary Enrollment-Distribution of Boys and Girls

(\%)

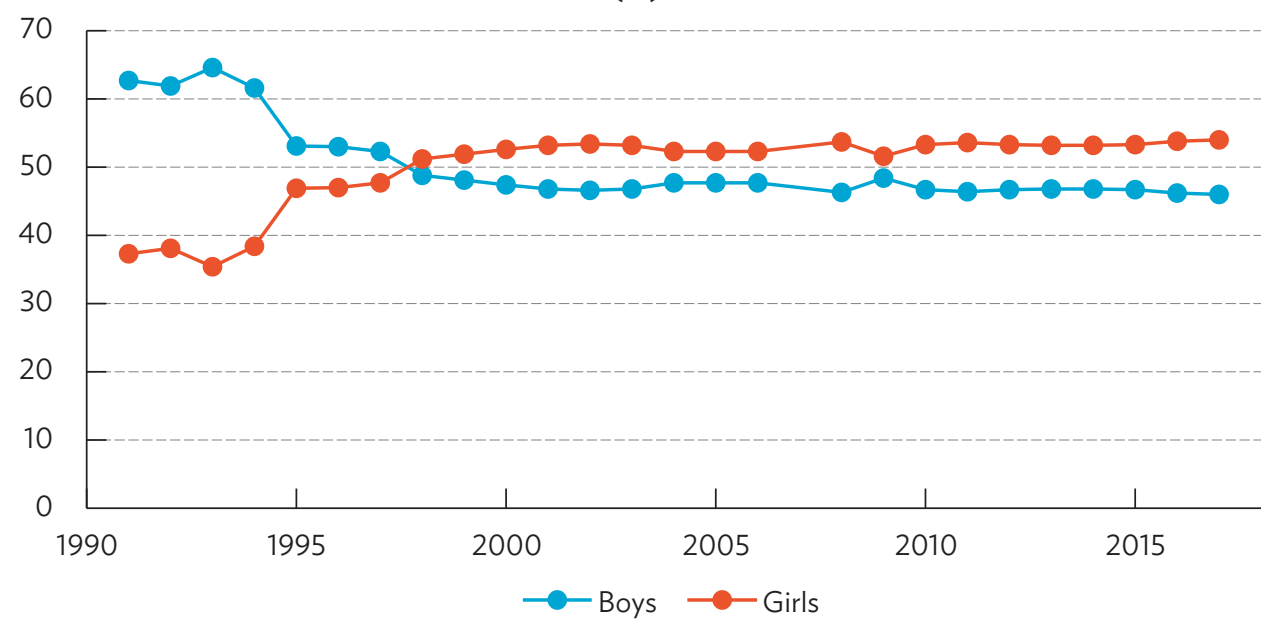

Sources: Bangladesh Bureau of Statistics. 1998. Bangladesh Statistical Yearbook of Bangladesh, 1998. Dhaka; Bangladesh Bureau of Education Information and Statistics. 2018. Bangladesh Education Statistics, 2017. Dhaka.

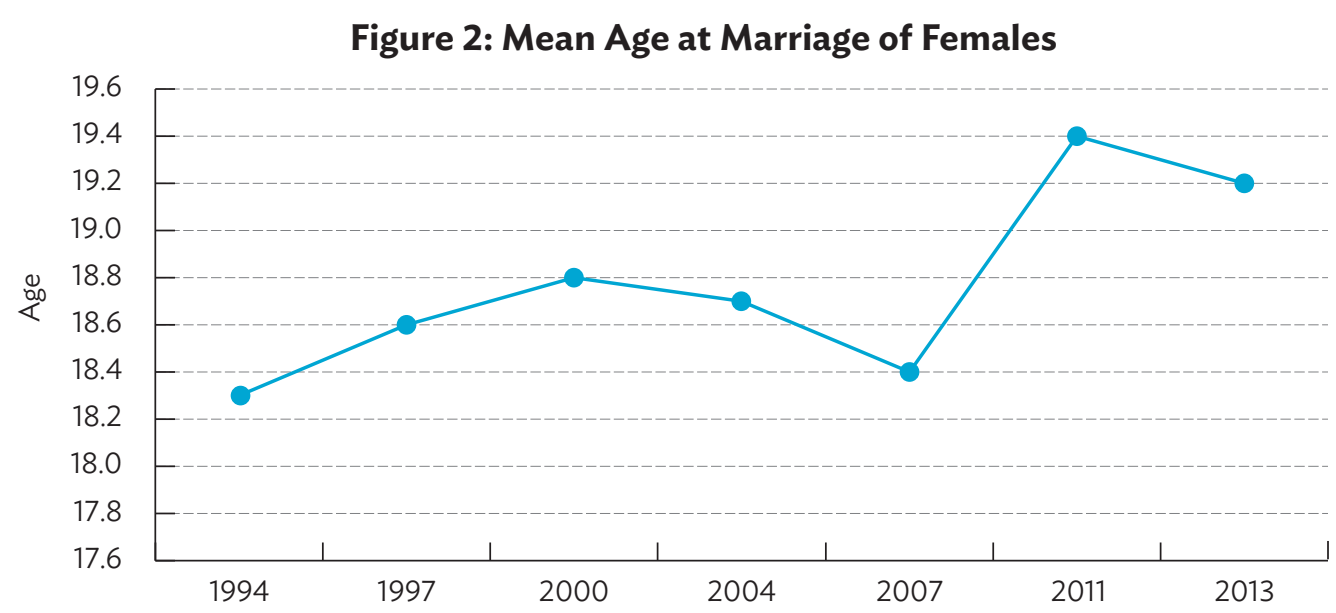

Source: World Bank. Data Catalog. https://datacatalog.worldbank.org/search?query=\%20mean-age-first-marriagefemale (accessed 20 July 2020).

13. As stated earlier, female education has both short- and long-term benefits; hence, any program supporting female education is expected to contribute to both the short- and long-term welfare of women. The study, using longitudinal surveys over 2 decades, addresses how a country such as Bangladesh has benefitted from FSSAP intervention soon after the program intervention and over time.

14. Understanding the long-term impacts of FSSAP becomes even more important now as a means of addressing the coronavirus disease (COVID-19) pandemic. As happened in other outbreaks such as the Ebola virus disease in Africa, female could have a higher risk of experiencing sexual abuse, early marriage, and pregnancy when schools close, resulting into school drop out (Giannini and Albrectsen 2020). UNESCO (2020) estimates that female upper secondary students are more at risk than male 
upper secondary students in South and West Asia. With the sharp drop in Bangladesh garment sector jobs in the ongoing pandemic (Hayashi and Matsuda 2020), females are disproportionately affected. The government needs to take early actions to implement gender-responsive education policies so that hard-won gains in gender equality will not be reversed (Park and Inocencio 2020).

15. This paper investigates the net effect of FSSAP on female education, and its induced effects on age at marriage; fertility; women's labor force participation; self-employment and nonfarm employment; as well as preference for sons and daughters. ${ }^{8}$ The paper also examines the induced effect of FSSAP on the characteristics of women's husbands (such as education and labor force participation). These effects are analyzed with individual level fixed effects (i.e., difference-indifferences or DID) and instrumental variable (IV) regressions using four rounds of household panel surveys over 2 decades (1991/92, 1998/99, 2010/11, and 2018). ${ }^{9}$ Finally, the paper addresses whether subsidies to female education are worth supporting to enhance socioeconomic and demographic changes, contributing to overall growth and development of a country such as Bangladesh.

\section{SIGNIFICANCE OF THE STUDY}

\section{A. What Do We Already Know?}

16. The World Bank has argued that programs targeted at girls can increase both girls' and boys' schooling (World Bank 2000). Of course, both boys and girls could benefit from subsidies, such as FSSAP, targeted only to girls because of induced income effects at the family level (Khandker, Pitt, and Fuwa 2003). At the same time, both boys and girls were increasingly enrolled in secondary school even before FSSAP was introduced. Therefore, it was not clear how much of the postintervention increase in schooling of girls was because of past trends (perhaps due to higher income growth) and how much to FSSAP intervention. Without a clear identification strategy, a trend analysis of school enrollment data does not provide any clear evidence of the net effect of school subsidies on the schooling of girls at the secondary level in Bangladesh. ${ }^{10}$

17. There is a large body of literature on the role of government school assistance programs in education in developing countries. For example, Afridi (2010), in a study of India's school meal program, finds that serving free, cooked meals at schools significantly improved girls' school attendance. More specifically, attendance of grade- 1 girls improved by more than 12 percentage points as a result of the free-meal program. But the study did not find any statistically significant impact of such a program on boys' school attendance. An evaluation of the Food for Education program (Ravallion and Wodon 2001) finds that food subsidies increased school attendance, but the effect

$8 \quad$ Parents are observed to prefer boys over girls, since monetary benefits and security traditionally accrue to parents from boys who stay at home after marriage; meanwhile, girls are married off and moved to husbands' houses. Although the preference for boys over girls is declining, it was a dominant feature of intrahousehold resource allocation, including investment in education of girls vis-à-vis boys, in Bangladesh and other South Asian countries (see Kabeer 2012, Akhter and Haque 2014).

9 The fiscal year of Bangladesh ends on 30 June.

10 The Food for Education program subsidizes primary school education of boys and girls and has been found to increase the schooling of both (Ravallion and Wodon 2001). Increased school enrollment of boys and girls at the secondary level might be a spillover effect of primary level school interventions, such as the Food for Education program. 
on child labor was mixed. Studying the same program, Ahmed and del Ninno (2002) find that the Food for Education program indeed increased enrollment and attendance of the primary-schoolgoing children and lowered their drop out rate. A study in Cambodia (Filmer and Schady 2011) finds that conditional cash transfers improved school attendance in that country by 25 percentage points. Similarly, evidence from Pakistan highlights an increase in girl's enrollment rates by 9 percentage points through the female secondary school stipend program (Chaudhury and Parajuli 2010). These studies did not look beyond the education outcomes. More evidence is needed on long-term effects of the gender-targeted school programs (ADB 2015).

18. A few studies focused on the role of FSSAP in enhancing educational outcomes at the secondary level. For example, Khandker, Pitt, and Fuwa (2003) and Schurmann (2009), examine the effect of FSSAP on the school enrollment of girls. These studies find substantial benefits of the FSSAP program in raising secondary school enrollment of girls relative to boys. According to the systematic review (Baird et al. 2013), the effect of FSSAP on schooling outcomes could be larger than that of PROGRESA in Mexico.

19. Some studies have also examined the long-term effects of the FSSAP. Shamsuddin (2015) finds that a full 5-year exposure to the stipend program can increase labor force participation among the girls by 6 percentage points. Hahn et al. (2017) consider a wider range of outcomes-short- and long-term -in their study on the FSSAP, using three rounds of cross-sectional time-series data. ${ }^{11}$ They find that compared to ineligible girls, those eligible for the stipend from FSSAP had 1.2 years more of education. The eligible girls also married later, had lower fertility, were more likely to work in the formal sector and marry educated men, and had more freedom in making decisions on their health care and household purchases.

20. Some studies also show that better investment in education of females eventually leads to better long-term outcomes. For example, Black, Devereux, and Salvanes (2008) find from a study in Norway and the United States that staying in school reduces teenage pregnancies. Breierova and Duflo (2004) find from a study in Indonesia that while parental education has a causal effect on the reduction of child mortality, the effects of mother's education is stronger than that of the father. In another study, mother's education improves infant's health (birth weight and gestational age) and lowers out-of-marriage pregnancy (Currie and Moretti 2003).

21. However, the aforementioned studies did not address the role of other policies that have impacted outcomes, such as girl's schooling relative to boys and their induced effects on women's labor force participation, which in turn might have induced positive effects on outcomes such as age at marriage, fertility, and children's education. For example, as Heath and Mobarak (2015) argue, recent labor force participation of women in garment factories could have also contributed to recent changes in socioeconomic outcomes including school enrollment, age at marriage, and childbirth. Although this finding may be driven by their data, including limited geographical coverage, as well as FSSAP

11 Our paper also estimates the long- and short-term effects of the female stipend program on women's education, marriage, and fertility. However, unlike Hahn et al.'s cross-sectional time series data, our data is of long panel of the same girls and boys surveyed over 2 decades (1991/92-2018) and therefore our econometric approach is different from that of Hahn et al. Hahn et al.'s identification strategy is derived from two sources: (i) exogeneous age cohort eligibility, and (ii) urban samples of the same age cohort (because the stipend program was introduced only in rural areas). Our data is from rural areas only, yet we have managed to introduce two sources of exogenous variations for identification strategies: (i) exogeneous age eligibility conditions and (ii) school-level stipend program placement (the program was not introduced to all rural schools at the same time). As will be discussed in the model section, Hahn et al.'s estimates are likely to be underestimated because of their comparison of rural girls against urban samples of the same age cohort. Moreover, their strategy lacks control for unobserved individual and household ability, which affects schooling outcomes, given the incentives provided through a stipend project. 
eligibility criterion used for analysis (Xu, Shonchoy, and Fujii 2019), the impact of FSSAP intervention introduced in the early 1990s could be overestimated if these changes are not controlled in a study of a female stipend program (and they are not in the Hahn et al. study, for example).

\section{B. Value-Added of the Longitudinal Impact Study}

22. During the last 2 decades, Bangladesh experienced marked demographic changes. For example, the total fertility rate declined from 3.7 children in 1991 to 2.1 children in 2011. The mean age at marriage of girls also increased, from 16.2 years in 1991 to 17.5 years by 2011 (Bangladesh Bureau of Statistics 2012). The percentage of women aged 20-24 who were married by age 18 declined from $73 \%$ in 1994 to 52\% in 2013. Contraceptive use among women (age 15-49) increased from 40\% in 1991 , to $61 \%$ in 2011 , and to $62 \%$ in $2014 .{ }^{12}$

23. This study aims to identify the net effects of FSSAP on a range of outcomes using long panel household surveys starting in 1991 (four rounds of surveys: 1991/92, 1998/99, 2010/11, and 2018). The study, which spans 26 years, addresses the fundamental question of what would have happened to Bangladesh's achievements in outcomes including female schooling, fertility, age at marriage, and contraceptive use; as well as women's occupational mobility, and preference for sons and daughters, had the FSSAP program not been introduced in the early 1990s. We argue that other studies (e.g., Hahn et al. 2017), do not fully address this fundamental policy issue, perhaps because the data were not of a household panel, but of cross-sectional time series.

24. This study also addresses the role of time-varying heterogeneity that affects schooling and other long-term outcomes. A major weakness of Hahn et al. (2017) is that the study is carried out using cross-sectional time series data (where urban household data provide controls in an exogeneous age cohort analysis), which cannot control for unobserved individual, household, and community characteristics (both time-invariant and time-varying heterogeneity). Moreover, using urban samples to control for the commensurate educational policies does not necessarily control for the unobserved time varying heterogeneity. This means that the estimates of Hahn et al. (2017) may not be consistent estimates of FSSAP program effects.

25. The study uses a longitudinal survey of 1,769 households from rural Bangladesh over 26 years (fiscal years 1992-2018), with rich information from each member of the households surveyed originally in 1991/92 and their information until 2018. The survey went through four rounds: 1991/92, $1998 / 99,2010 / 11$, and 2018, so the data covers the history of family members subject to the FSSAP intervention before and after it was introduced in 1994; as well as without and with a program introduced for certain cohorts and certain areas. Hence, the study has a number of features that address not only the weaknesses of study design of earlier studies, but also a number of policy issues important to identifying whether the female stipend program was worth supporting.

26. By using longitudinal household surveys over 26 years covering all members of relevant ages (0-20 in 1991/92), both before and after the introduction of FSSAP, this study addresses many of the methodological issues inherent in a time-series cross-sectional survey. The study uses a natural experimental design of exogeneous age-based eligibility conditions to estimate the effect of program intervention. Moreover, given the design of the intervention and survey data, where individual and household (both time invariant and time-varying) heterogeneity may not be controlled, we employ a quasi-experimental empirical strategy known as the instrumental variables or IV method within the DID framework to verify the robustness of impact estimates of FSSAP intervention.

12 World Bank. Contraceptive Prevalence, Any Methods (\% of women ages 15-49) - Bangladesh. https://data.worldbank.org/ indicator/SP.DYN.CONU.ZS?locations=BD (accessed 1 July 2020). 
27. The study also adds value by addressing several policy issues surrounding girls' schooling relative to boys. Gender disparity in schooling (especially secondary education) is not only induced by cost differences in educating girls relative to boys but is also triggered by preference for sons over daughters given potential benefits that accrue to parents. For example, because of greater market opportunities available to boys, sons get preferential treatment over girls in higher education. Boys can be employed readily and are likely to stay home after marriage, compared to girls who may not be able to get jobs due to social taboos and a lack of employment opportunities. Moreover, females in Bangladesh always move to their husband's home. The longitudinal data provide a history of births and schooling of cohorts of families exposed or unexposed to FSSAP intervention, which provides an opportunity to study the potential benefits of FSSAP in reducing preference for sons in human capital investments.

\section{DATA AND ITS MAJOR CHARACTERISTICS}

\section{A. Description of Data}

28. The data used for this study was first collected during 1991/92, financed by the World Bank, and administered by the Bangladesh Institute of Development Studies. The study examined the beneficial impacts of rural microcredit programs on household and individual welfare in rural Bangladesh. The survey collected information on household and individual demographic and socioeconomic characteristics, including age, gender, employment, income, asset, expenditure, and credit. For education, data were collected on individuals' school enrollment status, grade attainment, school expenditure, stipend or scholarship received, and so on. Besides collecting household data, the survey collected information on village characteristics such as infrastructure (roads, electricity, schools, markets, health facilities, banks, and so on); development programs (government and nongovernment safety nets, credit, and skill training programs); and wages, interest rates, and prices of consumer goods. The survey covered 1,769 households.

29. The first survey round was followed up by two surveys over the next 2 decades - one during 1998/99 and the other during 2010/11-which attempted to track previously surveyed households. Attrition among households was 7.4\% between 1991/92 and 1998/99, and 10\% between 1998/99 and 2010/11. ${ }^{13}$ The survey in 1998/99 (which was administered after the stipend was introduced in 1994) collected information on the amount of FSSAP stipend the girls were receiving (or received). However, since the focus of the surveys was not education, collection of relevant information was limited.

30. A fourth survey was carried out in 2018, funded by University of Tokyo Graduate School of Public Policy-this time with an exclusive focus on girls' education and other relevant outcomes. Unlike the earlier rounds, which tracked households, the 2018 survey tracked only a subset of individuals, who were aged 0-20 during the 1991/92 survey. Moreover, unlike the earlier rounds, which considered a household as "untraceable" (and therefore attrited) during a follow-up round if it moved from its original village, the 2018 survey attempted to contact all individuals, even if they moved to locations outside their original villages after the first round. This was done by visiting them if located within a reasonable distance from their original villages (15 kilometers), or by contacting them by mobile phone when they

13 This is household-level attrition. A household was considered attrited (considered dropped out) in a follow-up survey if it could not be found in the same village it was located in the previous round, or, in rare occasions, declined to be interviewed. 
were far away. ${ }^{14}$ The overall attrition rate among individuals (between 1991/92 and 2018) was 17.2\%. Attrition of individuals was attributed not only to whether they could not be traced or had died, but also whether the women declined to be interviewed, either in person or over the phone. ${ }^{15}$ Table A1.2 shows the sample distribution by divisions and reports other salient features of the sample.

31. The information collected covered schooling outcomes of girls and boys; women's outcomes on employment (occupation, place of work, years of employment, and income); marriage (age at marriage, place of marriage, dowry amount, etc.); husbands' characteristics (education, occupation, years of employment, and income); fertility (year of first birth, number of children ever born, children's sex, and so on); schooling status of the children; and empowerment indicators (intrahousehold bargaining power; more specifically, mobility, decision-making, financial autonomy, etc.). This survey constructed a panel dataset at the individual level, with a focus on those who were included in the 1991/92 survey, and at stipend-appropriate age at some point over the next 2 decades.

32. Using long panel household surveys and the age cohort of girls eligible to receive a stipend as the identifier-grades 6 and 9 in 1994; grades 6, 7, 9, and 10 in 1995; and all five grades from 1996 onward - the individual- and household-level data allow not only identification but also estimation of the long-term effects of a conditional cash transfer scheme such as the FSSAP program in reducing gender disparity in a society.

33. More specifically, the data helps us (i) use information on individual girls from four panels to measure progression in schooling, (ii) estimate the impact of the stipend using data from the exact year that the stipend started for each cohort, and (iii) construct a direct measure of stipend receipt as a potential policy instrument. Because of the panel nature of data at the individual level over a period of more than 2 decades, we use actual number of years the stipend was received by girls as potential endogenous variables and assess their impacts on outcomes after marriage (such as fertility and occupational outcomes).

34. We are able to determine if the stipend program has reduced gender disparity in schooling; and whether it has large effects on outcomes such as occupational choice, fertility, and gender preferences in children that may warrant the government's policy of continuation of a female stipend program in a country such as Bangladesh.

35. Household surveys from the first three rounds (1991/92, 1998/99, and 2010/11) show the schooling trends of boys and girls aged 5-29. The long panel data (1991/92, 1998/99, 2010/11, and 2018) show trends in marital outcomes such as age at marriage of girls, as well as their occupational patterns relative to those of husbands. The immediate effects of schooling intervention are to affect the schooling and marital outcomes of girls who are the beneficiaries of the stipend program.

36. Figure 3, panels $A$ and $B$ show grade attainment of girls and boys, respectively, by age group for three survey years. ${ }^{16}$ Five age groups are considered: 5-9, 10-14, 15-19, 20-24, and 25-29. In general, grade attainment increases with the increase in survey years, except for girls in 1998/99, who show a sharp drop in grade attainment at age group 25-29. Girls' grade attainment increases from age group 5-9 to age group 15-19, before it falls among subsequent age groups. On the other hand, boys' attainment continues to rise beyond age group 15-19, except for 1991/92, when attainment goes down after age group 20-24. However, the highest average grade attained by girls in 2010/11

\footnotetext{
14 Their phone numbers were collected from siblings or other family members still in the original villages.

15 The latter happened in particular for women from conservative families, who were not permitted to be interviewed (mostly by their husbands).

16 The last survey year, 2018, is not considered for these graphs because the sample during this year is a small subset (those who were 0-20 years old during the first round of survey, that is, 1991/92).
} 
(6.8 for age group 15-19) is slightly higher than that by boys in 2010/11 (6.6 for age group 25-29). Figure 3 panel A clearly shows that girls' performance during the stipend-eligibility years in 1998/99 and 2010/11 was better than or at least on par with boys' performance as shown in Figure 3 panel B.

\section{B. Descriptive Statistics of Outcome Variables}

37. Before exploring the causal relationship between FSSAP intervention and girls' outcomes, we look at the descriptive statistics of the outcomes. For this purpose, we group the girls by the exogenous eligibility criteria based on their age. As noted earlier, only girls who were attending grades 6-10 were

Figure 3: Grade Attainment by Survey Years
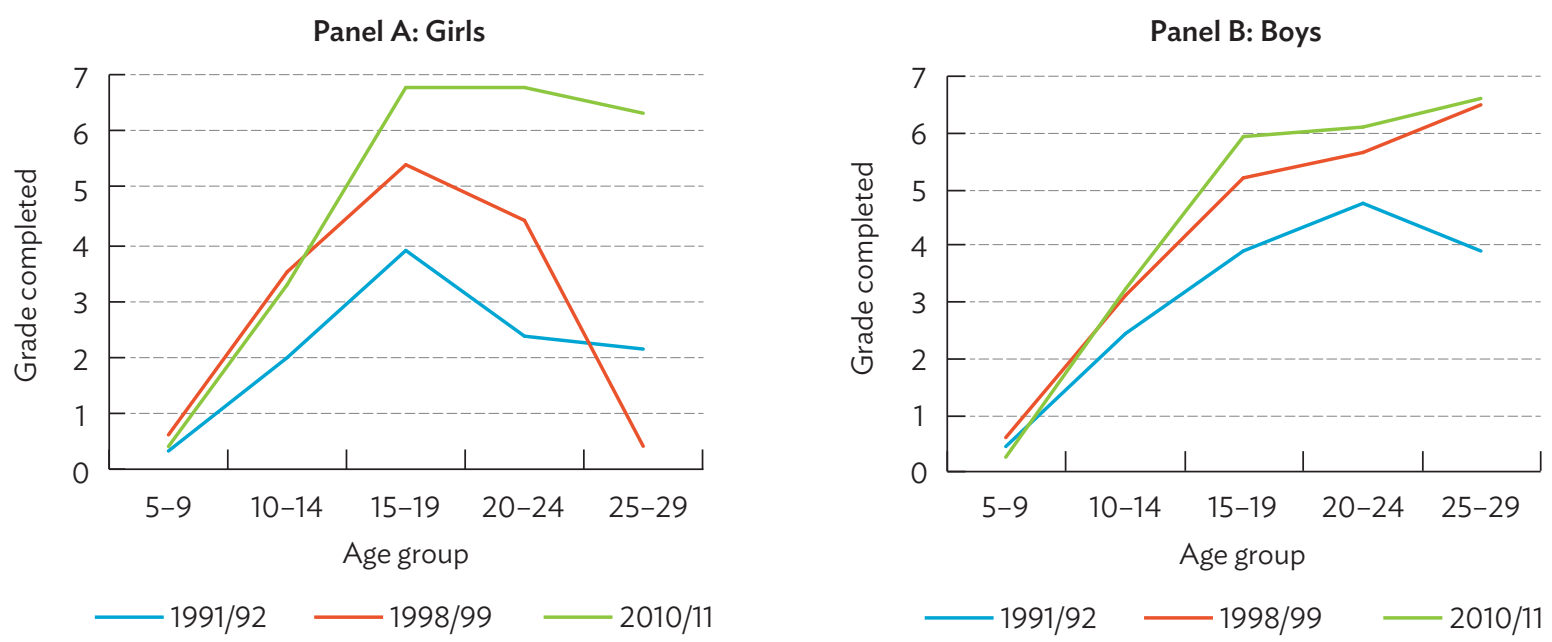

Sources: Bangladesh Institute of Development Studies-World Bank. 1992. Bangladesh Household Survey Data, $1991 / 92$. Dhaka; Bangladesh Institute of Development Studies-World Bank. 1999. Bangladesh Household Survey Data, 1998/99. Dhaka; Institute for Inclusive Finance and Development and World Bank. 2011. Bangladesh Household Survey Data, 2010/11. Washington, DC.

eligible for the stipend. Furthermore, while FSSAP was introduced in 1994, not all grades were eligible for the stipend in that year: grades 6 and 9 were eligible in 1994; grades 6, 7, 9, and 10 in 1995; and all five grades from 1996 onward. The Box that follows shows the differential exposure of girls to FSSAP. 
Box: Year-Specific Exposure to the Female Secondary Stipend and Assistance Program

\begin{tabular}{cccccc}
\hline Year & Grade 6 & Grade 7 & Grade 8 & Grade 9 & Grade 10 \\
\hline 1994 & 1994 cohort & 1993 cohort & 1992 cohort & 1991 cohort & 1990 cohort \\
\hline 1995 & 1995 cohort & 1994 cohort & 1993 cohort & 1992 cohort & 1991 cohort \\
\hline 1996 & 1996 cohort & 1995 cohort & 1994 cohort & 1993 cohort & 1992 cohort \\
\hline 1997 & 1997 cohort & 1996 cohort & 1995 cohort & 1994 cohort & 1993 cohort \\
\hline 1998 & 1998 cohort & 1997 cohort & 1996 cohort & 1995 cohort & 1994 cohort \\
\hline
\end{tabular}

Note: A "year cohort" is defined as a group of students entering secondary school in a particular year, with each cohort being identified by the year of entering grade 6 (entering class cohort of 1994, 1995, etc.). The shaded cells indicate the grade cohort eligible for the stipend in a given year, while white cells show the cohorts that are not eligible for stipend in a particular year.

Source: S. Khandker, M. Pitt, and N. Fuwa. 2003. Subsidy to Promote Girls' Secondary Education: The Female Stipend Program in Bangladesh. Washington, DC: World Bank.

38. The eligibility of the girls was determined using the following criteria:

(i) Girls born in 1983 or later (cohort 1) - expected to be in grade 6 in 1994 or later, and thus eligible (all 5 years of stipend duration).

(ii) Girls born between 1980 and 1982 (cohort 2) - expected to be in grade 9 from 1994 to 1996, and thus eligible while they were in grades 9-10 (2 years of stipend duration).

(iii) Girls born in 1979 or earlier (cohort 3) - expected to be in grades 10 or higher in 1994, and thus not eligible for FSSAP, and serve as the control group.

39. Based on this eligibility criteria, we examine short- and long-term outcomes of eligible and ineligible girls. ${ }^{17}$

40. Among the outcomes of interest, access to education outcomes is expected to improve first and shortly thereafter, as a result of exposure to the stipend program. Table 1 shows education outcomes of the girls during the four survey years. Since eligible girls were very young during the 1991/92 survey (age 11 or less), their outcomes were obviously worse than that of the ineligible girls (who were older). For example, the average grade attainment was 0.29 for eligible girls and 2.66 for ineligible girls in 1991/92, with the difference statistically significant. Over the subsequent surveys, however, eligible girls demonstrated higher grade attainment, perhaps because of their exposure to the stipend program; and by 2010/11, they outperform ineligible girls of the same age group. More specifically, eligible girls had an average attainment of grade 2.9 in 1998/99, grade 6.8 in 2010/11, and grade 7.1 in 2018. On the other hand, ineligible girls' grade attainment in those years was 4.3, 5.0, and 5.0, respectively. The trend is roughly the same for another two outcomes-cumulative enrollment (ever attended school) and secondary completion rate.

41. It is reasonable to assume that the benefits of FSSAP would extend beyond the education outcomes of the girls, particularly in employment outcomes. ${ }^{18}$ Table 2 shows that in 2010/11, employment outcomes of ineligible girls were better than those of eligible girls, although the

17 Reported outcomes are weighted means, where weights are calculated at the individual level.

18 While we report these findings for 2010/11 and 2018, 2018 findings are more meaningful as they allow a longer time for the benefits to be realized. 
Table 1: Female Secondary Stipend and Assistance Program-Descriptive Statistics of Education Outcomes by Stipend Eligibility: Girls

\begin{tabular}{|c|c|c|c|c|c|c|c|c|}
\hline \multirow[b]{2}{*}{ Outcomes } & \multicolumn{2}{|c|}{$1991 / 92$} & \multicolumn{2}{|c|}{ 1998/99 } & \multicolumn{2}{|c|}{ 2010/11 } & \multicolumn{2}{|c|}{2018} \\
\hline & Eligible & Ineligible & Eligible & Ineligible & Eligible & Ineligible & Eligible & Ineligible \\
\hline Ever attended & $\begin{array}{r}0.347 \\
(t=-7.80)\end{array}$ & 0.603 & $\begin{array}{r}0.893 \\
(t=9.00)\end{array}$ & 0.674 & $\begin{array}{r}0.944 \\
(t=10.65)\end{array}$ & 0.728 & $\begin{array}{r}0.944 \\
(t=10.61)\end{array}$ & 0.729 \\
\hline Grade completed & $\begin{array}{r}0.289 \\
(t=-19.55)\end{array}$ & 2.660 & $\begin{array}{r}2.936 \\
(t=-6.30)\end{array}$ & 4.348 & $\begin{array}{r}6.785 \\
(t=6.76)\end{array}$ & 4.960 & $\begin{array}{r}7.101 \\
(t=7.02)\end{array}$ & 5.024 \\
\hline Completed secondary level & $\begin{array}{r}0 \\
(t=-6.61)\end{array}$ & 0.047 & $\begin{array}{r}0.015 \\
(\mathrm{t}=-8.63)\end{array}$ & 0.131 & $\begin{array}{r}0.228 \\
(t=1.68)\end{array}$ & 0.181 & $\begin{array}{r}0.251 \\
(t=2.19)\end{array}$ & 0.188 \\
\hline N & 894 & 269 & 894 & 269 & 894 & 269 & 894 & 269 \\
\hline
\end{tabular}

Note: Sample includes girls aged 0-20 during the 1991/92 survey. t-statistics in parentheses refer to the difference between eligible and ineligible girls.

Sources: Bangladesh Institute of Development Studies-World Bank. 1992. Bangladesh Household Survey Data, 1991/92. Dhaka; Bangladesh Institute of Development Studies-World Bank. 1999. Bangladesh Household Survey Data, 1998/99. Dhaka; Institute for Inclusive Finance and Development and World Bank. 2011. Bangladesh Household Survey Data, 2010/11. Washington, DC; and University of Tokyo Graduate School of Public Policy. 2018. Bangladesh Household Survey Data, 2018. Tokyo.

Table 2: Female Secondary Stipend and Assistance Program-Descriptive Statistics of Employment, Marriage, and Spouse-Related Outcomes by Stipend Eligibility: Girls

\begin{tabular}{|c|c|c|c|c|}
\hline \multirow[b]{2}{*}{ Outcomes } & \multicolumn{2}{|c|}{$2010 / 11$} & \multicolumn{2}{|c|}{2018} \\
\hline & Eligible & Ineligible & Eligible & Ineligible \\
\hline \multirow[t]{2}{*}{ Employed } & $\begin{array}{r}0.036 \\
(t=-4.42)\end{array}$ & 0.103 & $\begin{array}{r}0.112 \\
(t=-1.81)\end{array}$ & 0.153 \\
\hline & $N=894$ & $N=269$ & $N=894$ & $N=269$ \\
\hline \multirow[t]{2}{*}{ Self-employed } & $\begin{array}{r}0.006 \\
(t=-1.42)\end{array}$ & 0.015 & $\begin{array}{r}0.030 \\
(t=-1.43)\end{array}$ & 0.048 \\
\hline & $N=894$ & $N=269$ & $N=894$ & $N=269$ \\
\hline \multirow[t]{2}{*}{ Employed in nonfarm sector } & $\begin{array}{r}0.034 \\
(t=-4.61)\end{array}$ & 0.103 & $\begin{array}{r}0.110 \\
(t=-1.79)\end{array}$ & 0.149 \\
\hline & $N=859$ & $N=304$ & $N=859$ & $N=304$ \\
\hline \multirow[t]{2}{*}{ Husband's grade completed } & $\begin{array}{r}5.593 \\
(t=5.57)\end{array}$ & 3.660 & $\begin{array}{r}6.682 \\
(t=2.05)\end{array}$ & 5.972 \\
\hline & $N=762$ & $N=254$ & $N=856$ & $N=255$ \\
\hline \multirow[t]{2}{*}{ Husband is employed } & $\begin{array}{r}0.911 \\
(t=16.31)\end{array}$ & 0.499 & $\begin{array}{r}0.996 \\
(t=3.50)\end{array}$ & 0.971 \\
\hline & $N=762$ & $N=254$ & $N=856$ & $N=255$ \\
\hline \multirow[t]{2}{*}{ Husband is self-employed } & $\begin{array}{r}0.496 \\
(t=6.70)\end{array}$ & 0.264 & $\begin{array}{r}0.519 \\
(t=-2.40)\end{array}$ & 0.603 \\
\hline & $N=762$ & $N=254$ & $N=856$ & $N=255$ \\
\hline Husband is employed in nonfarm sector & $\begin{array}{r}0.678 \\
(t=8.27)\end{array}$ & 0.398 & $\begin{array}{r}0.770 \\
(t=3.78)\end{array}$ & 0.655 \\
\hline $\mathrm{N}$ & $N=762$ & $N=254$ & $N=856$ & $N=255$ \\
\hline
\end{tabular}

Note: Sample includes girls aged 0-20 during 1991/92 survey. t-statistics in parentheses refer to the difference between eligible and ineligible girls.

Sources: Institute for Inclusive Finance and Development and World Bank. 2011. Bangladesh Household Survey Data, 2010/11.

Washington, DC; and University of Tokyo Graduate School of Public Policy. 2018. Bangladesh Household Survey Data, 2018. Tokyo. 
statistical significance of their differences diminishes from 2011 to 2018 . This is probably because room to grow still existed for employment outcomes of the eligible girls in $2018 .{ }^{19}$ Table 2 also reports women's husband's outcomes. Husbands of the eligible girls, in 2018, are found to be more educated and employed than those of the ineligible girls. The husbands of eligible girls are less likely to be self-employed (52\%) but more likely to be employed in the nonfarm sector (77\%) in 2018, compared to the husbands of ineligible girls. To what extent these outcomes can be causally linked to FSSAP is explored in section $\mathrm{V}$.

42. The final set of women's outcomes we look at are related to marriage and fertility (Table 3). The age at marriage was 17.6 for eligible girls and 18.2 for ineligible girls in 2010/11. However, in 2018, by which time more of the eligible girls had married, age of marriage had risen to 18.5 years for both groups. Eligible women are more likely to use contraceptives and have a lower total fertility than ineligible women in 2018, and the differences are statistically significant. ${ }^{20}$ More specifically, $70 \%$ of the married eligible women are found to use some form of contraception in 2018, compared to $49 \%$ of the married ineligible women. In 2018, total fertility of the two groups was 2.04 for eligible women, and 2.34 for ineligible women. While sons are preferred to daughters across years, regardless of the eligibility of the women, the number of preferred children (both boys and girls) is found to be lower among eligible women than among ineligible women.

\section{Table 3: Female Secondary Stipend and Assistance Program-Descriptive Statistics of Fertility and Child Preference by Stipend Eligibility: Girls}

\begin{tabular}{|c|c|c|c|c|}
\hline \multirow[b]{2}{*}{ Outcomes } & \multicolumn{2}{|c|}{ 2010/11 } & \multicolumn{2}{|c|}{2018} \\
\hline & Eligible & Ineligible & Eligible & Ineligible \\
\hline \multirow[t]{2}{*}{ Age at marriage (years) } & $\begin{array}{r}17.644 \\
(t=-2.64)\end{array}$ & 18.196 & $\begin{array}{r}18.526 \\
(t=0.22)\end{array}$ & \\
\hline & $N=762$ & $N=254$ & $N=762$ & $N=254$ \\
\hline \multirow[t]{2}{*}{ Use of contraceptives by currently married women } & $\begin{array}{r}0.630 \\
(t=-0.78)\end{array}$ & 0.665 & $\begin{array}{r}0.701 \\
(t=5.09)\end{array}$ & 0.490 \\
\hline & $N=696$ & $N=126$ & $N=786$ & $N=134$ \\
\hline \multirow[t]{2}{*}{ Total fertility of currently married women } & $\begin{array}{r}1.394 \\
(t=-8.36)\end{array}$ & 2.103 & $\begin{array}{r}2.035 \\
(t=-3.47)\end{array}$ & 2.335 \\
\hline & $N=664$ & $N=125$ & $N=783$ & $N=134$ \\
\hline \multirow[t]{2}{*}{ Preferred number of sons by currently married women ${ }^{a}$} & $\begin{array}{r}1.087 \\
(t=-2.63)\end{array}$ & 1.168 & $\begin{array}{r}1.051 \\
(t=-3.70)\end{array}$ & 1.142 \\
\hline & $N=518$ & $N=115$ & $N=772$ & $N=130$ \\
\hline Preferred number of daughters by currently married women ${ }^{a}$ & $\begin{array}{r}0.531 \\
(t=-2.01)\end{array}$ & 0.640 & $\begin{array}{r}0.594 \\
(t=-1.79)\end{array}$ & 0.680 \\
\hline $\mathrm{N}$ & $N=516$ & $N=117$ & $N=769$ & $N=132$ \\
\hline
\end{tabular}

a These figures refer to time before the first child was born.

Note: Sample includes girls aged 0-20 during 1991/92 survey. t-statistics in parentheses refer to the difference between eligible and ineligible girls.

Sources: Institute for Inclusive Finance and Development and World Bank. 2011. Bangladesh Household Survey Data, 2010/11. Washington, DC; and University of Tokyo Graduate School of Public Policy. 2018. Bangladesh Household Survey Data, 2018. Tokyo.

\footnotetext{
19 Note that eligible girls are much younger than ineligible girls, separated by an average age difference of 11 years, and a good number of the eligible girls may not have entered the job market yet.

20 Total fertility is defined by the total number of live children born to a woman.
} 
43. Besides looking at girls' outcomes, we also consider boys' education outcomes in this study to capture what is called "sibling effects". It is possible that if a household has eligible girls, the boys in the household may have better education outcomes than those in a household with no eligible girls. ${ }^{21}$ Table 4 shows that from 1998/99 onward, boys' education outcomes in households with eligible girls improved more than those in households that do not have any eligible girls. For example, the cumulative school enrollment rate for boys in households with eligible girls is $87.2 \%$ in 1998/99, 94.2\% in 2010/11, and $94.2 \%$ in 2018. Compared to that, cumulative enrollment rate for boys in households with no eligible girls is $69.9 \%, 79.9 \%$, and $80.7 \%$, respectively, in the same years. Based on the discussion on the descriptive statistics of the outcome indicators, we can summarize, without implying any causality, that education and marital outcomes for eligible girls are better than those for ineligible girls, and a similar trend also exists for boys' education outcomes.

Table 4: Female Secondary Stipend and Assistance Program-Descriptive Statistics of Education Outcomes of Boys Based on Stipend Eligibility of the Girls in Households

\begin{tabular}{|c|c|c|c|c|c|c|c|c|}
\hline \multirow[b]{2}{*}{ Outcomes } & \multicolumn{2}{|c|}{$1991 / 92$} & \multicolumn{2}{|c|}{$1998 / 99$} & \multicolumn{2}{|c|}{$2010 / 11$} & \multicolumn{2}{|c|}{2018} \\
\hline & Eligible & Ineligible & Eligible & Ineligible & Eligible & Ineligible & Eligible & Ineligible \\
\hline Ever attended & $\begin{array}{r}0.489 \\
(t=-4.61)\end{array}$ & 0.682 & $\begin{array}{r}0.872 \\
(t=7.15)\end{array}$ & 0.699 & $\begin{array}{r}0.942 \\
(\mathrm{t}=9.02)\end{array}$ & 0.799 & $\begin{array}{r}0.942 \\
(t=8.63)\end{array}$ & 0.807 \\
\hline Grade completed & $\begin{array}{r}1.169 \\
(\mathrm{t}=-13.95) \\
\end{array}$ & 3.910 & $\begin{array}{r}3.599 \\
(t=-4.51) \\
\end{array}$ & 4.681 & $\begin{array}{r}6.711 \\
(t=3.97) \\
\end{array}$ & 5.791 & $\begin{array}{r}7.315 \\
(t=5.31) \\
\end{array}$ & 5.924 \\
\hline $\begin{array}{l}\text { Completed } \\
\text { secondary level }\end{array}$ & $\begin{array}{r}0.009 \\
(t=-2.54)\end{array}$ & 0.031 & $\begin{array}{r}0.054 \\
(t=-8.63)\end{array}$ & 0.207 & $\begin{array}{r}0.265 \\
(t=1.05)\end{array}$ & 0.240 & $\begin{array}{r}0.286 \\
(t=1.59)\end{array}$ & 0.247 \\
\hline $\mathrm{N}$ & 1,534 & 183 & 1,449 & 268 & 1,297 & 420 & 1,301 & 416 \\
\hline
\end{tabular}

Note: Sample includes girls aged 0-20 during the 1991/92 survey. t-statistics in parentheses refer to the difference between eligible and ineligible girls.

Sources: Bangladesh Institute of Development Studies-World Bank. 1992. Bangladesh Household Survey Data, 1991/92. Dhaka; Bangladesh Institute of Development Studies-World Bank. 1999. Bangladesh Household Survey Data, 1998/99. Dhaka; Institute for Inclusive Finance and Development and World Bank. 2011. Bangladesh Household Survey Data, 2010/11. Washington, DC; and University of Tokyo Graduate School of Public Policy. 2018. Bangladesh Household Survey Data, 2018. Tokyo.

21 This is perhaps because of income effects caused by cash transfers to families with eligible girls. 


\section{ESTIMATION STRATEGY}

44. Given that our data covers information spanning more than 2 decades for the same individuals (that is, long panel data), one approach would be to compare cohorts of children (girls) covered by FSSAP (the treated group); and those not covered, i.e., too old to be covered (the control group). A possible way to estimate the FSSAP effect is to use difference-in-differences (DID) method, similar to the one used by Hahn et al. (2017). ${ }^{22}$ Given the simplest case of two-period setting where the time $t=0$ represents before the program introduction and $t=1$ is after program implementation, and letting $T_{t}^{T}$ and $T_{t}^{C}$ be the average outcomes for program beneficiaries (FSSAP participants) and nonbeneficiaries (nonparticipants of FSSAP), respectively, in time $t$, the average program impact can be estimated by following formula:

$$
D I D=E\left(T_{1}^{T}-T_{0}{ }^{T} \mid T_{1}=1\right)-E\left(T_{1}{ }^{C}-T_{0}{ }^{C} \mid T_{1}=0\right)
$$

where, $T_{1}$ denotes participation and $T_{0}$ is nonparticipation. In essence, the impact is the difference in the changes in average outcome from pre- to post-intervention period for participants and nonparticipants. The outcome can also be specified for individual $i$ using following equation,

$$
Y_{i}=a+\beta T_{i}+\gamma t_{i}+\delta\left(T_{i} * t_{i}\right)+\varepsilon_{i}
$$

where, $T$ is the treatment variable ( 1 for participants and 0 for nonparticipants); $t$ is the time dummy ( 0 for pre-intervention and 1 for post-intervention); $\alpha, \beta, \gamma$, and $\delta$ are unknown parameters to be estimated; and $\varepsilon$ is the random error term. The coefficient $\delta$ of the interaction gives the average DID impact of the treatment. ${ }^{23}$

45. The most important assumption behind DID estimation is the parallel-trend assumption, expressed as $\operatorname{Cov}\left(\varepsilon_{i}, T_{i}^{*} t_{i}\right)=0$, which says that in the absence of intervention, the participants would have followed the same trend as the nonparticipants for the outcomes of interest. Outcomes may vary because of both observed and unobserved factors, but the parallel-trend assumption requires that these factors remain constant over time; or that their effects on the participants and nonparticipants remain the same; otherwise, impacts estimated by DID would be biased. In reality however, it is hardly possible to ensure that these factors would remain constant, or that their effects be the same across participants and nonparticipants alike. A solution is to control for the effects of these factors, which will help estimate the unbiased effects of the treatment. This is done implementing a fixed-effects model, a generalized version of DID. Fixed-effects model is also suitable when the panel consists of more than two rounds, which is the case for this study.

46. As we have enough within-household variations in FSSAP eligibility, we use individual-level fixed effects (i.e., if there are enough siblings to allow us to compare older versus younger cohorts of girls within the same households but controlling for birth order effects). This is done by defining three types of cohorts based on the timing of FSSAP introduction (shown in section III). We now turn our attention to models specific to exogenous eligibility criteria and endogenous treatment.

\footnotetext{
22 Regression discontinuity could be another approach but it was not explored in detail because of the limited sample size near the vicinity of cut-off points (cohorts) of FSSAP.

23 This is the so-called intent-to-treat (ITT) effect discussed further later.
} 


\section{A. Intent-to-Treat Effects}

47. To estimate the effects of exogenous eligibility on a range of outcomes, i.e., intent-to-treat effects or ITT (in the manner of Hahn et al. 2017), we can write the following outcome equation,

$$
Y_{i t}=\alpha+\beta X_{i t}+\gamma_{1} C 1_{i t}+\gamma_{2} C 2_{i t}+\delta T_{t}+\mu_{i}+\varepsilon_{i t}
$$

where, $Y_{i t}$ denotes the outcome variables of interest, such as completed grade of girl $i$ in year $t$; $X_{i t}$ is a vector of individual, household- and community-level observed characteristics; ${ }^{24} \mathrm{Cl}_{i t}$ and $C 2_{i t}$ are dummy variables indicating cohorts 1 and 2 (with a value of 1 if the girl is in cohort 1 or 2 , respectively, and 0 otherwise); $T_{t}$ is the variable capturing survey year; ( $T$ is presented as a set of dummy variables for different survey rounds). $\mu_{i}$ represents unobserved individual, household, or community-level determinants of the outcomes that are time-invariant; $\varepsilon_{i t}$ is the randomly distributed error term; and $\beta, \gamma_{1}, \gamma_{2}$, and $\delta$ are unknown parameters to be estimated. We are particularly interested in $\gamma_{1}$ and $\gamma_{2}$, which capture the cohort effects.

48. A commonly used approach to implementing fixed effects regression for panel data covering more than two data points involves what is called demeaning, which takes the difference of the observed value of a variable at a time point and its mean across all time points. Thus, demeaning of equation (3) yields

$$
\begin{aligned}
& \left(Y_{i t}-\bar{Y}_{i}\right)=\beta\left(X_{i t}-\bar{X}\right)+\gamma_{1}\left(C 1_{i t}-\overline{C 1_{i}}\right)+\gamma_{2}\left(C 2_{i t}-\overline{C 2_{i}}\right)+\delta\left(T_{t}-\bar{T}\right)+\left(\mu_{i}-\bar{\mu}_{i}\right)+\left(\varepsilon_{i t}-\overline{\varepsilon_{i}}\right) \\
& \Rightarrow \Delta Y_{i t}=\beta \Delta X_{i t}+\gamma_{1} \Delta C 1_{i t}+\gamma_{2} \Delta C 2_{i t}+\delta \Delta T_{t}+\Delta \varepsilon_{i t}
\end{aligned}
$$

49. Since unobserved components are eliminated, equation (4) can be used to estimate cohort effects. If we take into account the heterogeneous geographical program placement, we can modify equation (4) in the following way:

$$
\Delta Y_{i t}=\beta \Delta X_{i t}+\gamma_{1} \Delta C 1_{i t}+\gamma_{2} \Delta C 2_{i t}+\rho_{1} \Delta\left(C 1_{i t} * P_{i t}\right)+\rho_{2} \Delta\left(C 2_{i t} * P_{i t}\right)+\delta \Delta \mathrm{T}_{t}+\Delta \varepsilon_{i t}
$$

where, $P_{i t}$ is the exogenous program placement dummy, and $\rho_{1}$ and $\rho_{2}$ are parameters to be estimated.

\section{B. Treatment-on-the-Treated Effects}

50. We can write the outcome equation for FSSAP participation in the following way:

$$
Y_{i t}=a+\beta X_{i t}+\gamma S_{i t}+\delta T_{t}+\mu_{i}+\eta_{i t}+\varepsilon_{i t}
$$

where, $S_{i t}$ is a dummy variable indicating whether girl $i$ actually received any stipend during year $t$ (its value is 1 if she did, 0 if she did not); $\eta_{i t}$ is the time-varying unobserved individual, household- or community-level determinants of the outcomes of interest. The demeaned equation corresponding to equation (6) is

$$
\Delta Y_{i t}=\beta \Delta X_{i t}+\gamma \Delta S_{i t}+\delta \Delta T_{t}+\Delta \eta_{i t}+\Delta \varepsilon_{i t}
$$

24 A wide range of variables are used as controls. Examples include age and school characteristics at individual level; age, sex, and education of the household head; number of adult males and females; agricultural land-holding at household level; and infrastructure, development programs, and price of consumable goods at community level. 
51. Here the parameter of interest is $\gamma$, which captures the average treatment-on-the-treated (TOT) effects of FSSAP participation. A variation of equation (7) can be made into the following way when we are interested in the effects of differential program exposure instead of average participation effects:

$$
\Delta Y_{i t}=\beta \Delta X_{i t}+\gamma \Delta D_{i t}+\delta \Delta T_{t}+\Delta \eta_{i t}+\Delta \varepsilon_{i t}
$$

where $D_{i t}$ is the duration of stipend (in years) that girl $i$ received until year $t$, with values ranging from 1 to 5 for stipend recipients and 0 for the control group. Since the unobserved term $\eta_{i t}$ remains in equations (7) and (8), an ordinary least squares implementation of these equations will result in biased estimations of the treatment effects. We discuss next how to resolve such endogeneity biases.

52. One possible problem with the assumption of uniformity of schooling age across cohorts is that if the reported age is measured with error (of classical type), then our estimate using the eligibility conditions based on observed ages could suffer from attenuation bias even if the girls enroll and progress on time. And, perhaps more importantly, we do not know how many of the girls delay school enrollment or repeat grades. This means we do not know whether the extent of such noncompliance is large enough to make the above assumption unconvincing. However, our survey collected a few pieces of information to minimize misclassification of stipend status, such as age at which girls started schooling, current age, and current grade. Moreover, since we have household-level data before and after the 1994 FSSAP intervention, it will be possible to judge how flawed our compliance restriction of school-age is across different age cohorts.

53. The assumption of uniformity of schooling age across cohorts may not always be valid because children may enroll in schools later than the appropriate age, repeat grades, and so on. In addition, older children may join schools, skip some normal progression with help (such as through bridge camps), and leave schools on and off. We are still able to use the 1991 schooling status of children (pre-FSSAP, thus predetermined) to identify those unlikely to be eligible (e.g., those above a certain age and not or never enrolled so that it would have been impossible to qualify when FSSAP started in 1994), and classify all others as potentially eligible. That is, we could identify from the 1991/92 and 1998/99 follow-up panel data of those most likely eligible (girls either in grades 6 or 9 as of 1994) and consider them as endogenously treated. We apply an IV method to estimate the program effects based on the assumptions that cohort-eligibility status as defined earlier serves as instruments.

54. Another reason for using the IV in the fixed effect approach (that is, fixed effects instrumental variable $[\mathrm{FE}-\mathrm{IV}]$ ) is that we can see in both fixed effects formulation of equations (7) and (8), demeaning eliminates all time-invariant variables, and leaves time-varying variables for analysis. An unobserved time varying determinant $(v)$ remains in the equation is a concern. However, the effects of unobserved determinants of the outcomes can be controlled for by using the exogenous eligibility conditions as instruments for the actual receipt of stipend at different grades.

55. The data analysis provides opportunities to net out the role of possible contributions to secondary schooling of a major intervention called Food for Education at the primary school level. This poses the additional issue of identifying the effects of Food for Education versus FSSAP. What we could do is to compare the same cohort-based effects between boys and girls and infer that the difference in outcomes may be due to FSSAP — an intervention at the secondary level.

56. As for possible outcome variables for analysis, given that the oldest cohort covered by FSSAP in 1994 was around age 36 as of 2018 when the fourth round of the survey was conducted, we could look at the long-run consequences of an intervention: age at marriage, as well as own occupation and income, and husband's occupation and income, reproductive behavior, and preference for sons and daughters. Thus, using alternative estimation methods, we explore a wide range of outcomes besides the education outcomes. 
57. Since the difference in outcomes between cohorts 1-2 and 3 may capture cohort effects in addition to stipend effects, Hahn et al. (2017) used urban girls corresponding to cohorts 1-3 as an additional control group. ${ }^{25}$ While our study uses a similar DID approach (more specifically, the generalized implementation, fixed effects), it adds additional value through various enhancements as discussed below.

(i) First, we use individual-level panel data from four data points, which allows us to control for individual fixed effects. This means that self-selection bias due to unobserved factors is controlled for as long as they are time-invariant.

(ii) We also consider the effects of time-varying unobserved factors, if any, which may influence participation and outcomes. We do so by controlling for pre-intervention (initial) conditions, as we have a data point in 1991/92 that is 3 years before the FSSAP program was introduced. The literature has established that unobserved heterogeneity can, to a large extent, be correlated with initial conditions (Heckman 1981; Chamberlain 1984; Arulampalam, Booth, and Taylor 2000). ${ }^{26}$

(iii) While Hahn et al. (2017) take into account the variation in the timing of the FSSAP program introduction years (1994-1996), it does not consider the geographical variation of program implementation during those years. Geographical variation existed, because while FSSAP was introduced during 1994-1996 (Box 1), the program in reality did not reach all schools during those 3 years. More specifically, only $37 \%$ of the sample villages received the program in 1994, 23\% in 1995, and so on, and it was not until 1999 that FSSAP was available in all sample villages. ${ }^{27}$ This means that a share of the girls were qualified for the program but could not participate as it was not available in their schools. ${ }^{28}$ Our analysis takes this variation into account.

(iv) Hahn et al. (2017) determine program participation based strictly on age, not on the actual grades attended by the girls, and so program participation status may have been misclassified for some girls during the initial years of program implementation-girls who started schooling late may have been mistakenly considered nonparticipants when they were in fact participants, and vice versa. In contrast, we determine program participation based on the actual grades attended by the girls as opposed to program eligibility based on age.

(v) Hahn at al. (2017) assume that all girls, once qualified, participated in the FSSAP program and continued to grade 10; that is how they came up with two discrete program participation lengths -2 years and 5 years. However, such an assumption may not always be correct. Some qualified girls did not participate in the program, perhaps on religious grounds. ${ }^{29}$ Moreover, some girls, after starting participation, did not continue to completion-possibly because they could not maintain the required minimum score of

25 Note that differences between cohorts 1-2 and cohort 3 capture not only differences in cohorts, but also changes in corresponding educational policies over time. This is why Hahn et al. (2017) used urban samples of the same age cohorts as an additional control, besides the age-cohort eligibility conditions. This, of course, does not control for the unobserved variations between urban and rural households or individuals.

26 Initial conditions can be controlled for in two ways in a panel setup: by including pre-intervention variables (those that might have influenced program participation) as additional controls in the fixed effects estimation regression, or by implementing propensity-score based weighted fixed effects estimation.

27 It was most likely due to administrative reasons that FSSAP could not reach all villages during 1994-1996. The 1998/99 follow-up survey includes a component for surveying all primary and secondary schools that the children from the sample households were attending. Findings from the school survey revealed that schools received the program in different years extending until 1999.

28 Our data suggest that about $5 \%$ of the eligible households missed out on the program because of program placement heterogeneity.

29 Note that the FSSAP program was meant mostly for impoverished households in rural areas; thus, it should not come as a surprise that some better-off households opted not to participate on religious grounds. 
$45 \%$ in the examinations or their parents wanted them to get married. In our estimation, we are able to determine the program duration of the girls more accurately, using multiple pieces of information: current age, age of starting school, grades currently attending (if still in school), and age of leaving school (if out of school). Thus, we get different variations in program duration, ranging from 1 to 5 years, unlike just two ( 2 and 5 years) used in Hahn et al. (2017). Overall, while we do not have a comparable urban sample of girls as an additional control group, unlike the one used in Hahn et al. (2017), our data vary enough within the rural sample for our identification strategy to work.

\section{Data Issues Relevant to Estimation}

58. Panel data are suitable for studying dynamic issues and resolving endogeneity of program participation, but they are also not without any limitations. The most critical factor to consider with panel data is the issue of attrition. Attrition is especially critical when the gaps between subsequent panel rounds are wide, which is the case in this study where the first (1991/92) and the last round (2018) has a gap of 26 years. Another issue that we investigate is to what extent the participants and nonparticipants are balanced at baseline.

\section{Attrition Bias Test}

59. As mentioned in section III, the attrition rate of the individuals was $17.2 \%$ from $1991 / 92$ to 2018 that is, less than $0.7 \%$ a year. Given the long duration between the first and fourth round (26 years), the attrition is not high, which was possible because of the efforts made by survey enumerators to contact target individuals, even when they moved far away. As for attrition in panel data analysis, what is important is not so much the extent of attrition but whether attrition is nonrandom. If attrition is nonrandom, it may create a sample selection bias, which could not be resolved using the survey sample weights. In that case, we need to correct sample selection bias using one of the established ways - such as inverse Mills ratio or inverse probability weighting approach. The first technique can be used if we can identify the selection with some identifying variables, and second one uses a weight based on the predicted probability of attrition, estimated using a selection model.

60. To assess the nature of attrition, we first compare the baseline (1991/92) socioeconomic characteristics (the control variables used in the estimation regression) between lost (attrited) individuals and those who stayed across the survey rounds. In particular, we want to find out if attrition is related to variables indicative of socioeconomic welfare of households and communities. There are a few well-known studies on attrition showing that attrition is negatively associated with socioeconomic welfare of the households (e.g., Alderman et al. 2000; Fitzgerald, Gottschalk and Moffitt 1998; Thomas, Frankenberg and Smith 2001; Ziliak and Kniesner 1998). For example, Fitzgerald, Gottschalk, and Moffitt (1998) found from the Michigan Panel Study of Income Dynamics that households with lower earnings, lower educational levels, and lower marriage propensities are more like to be subject to attrition. This means that attrition is less likely to be random. Table A1.3 shows the means of socioeconomic variables for attrited households and those that remained throughout the panel rounds. Among the household characteristics, those that signify social and physical welfare (household head's education and household land asset) are not different between the two groups (t-statistics of the difference is not statistically significant). However, findings on the village-level characteristics show that village accessibility and electrification rate are higher for attrited households than those that stayed. Findings also show that attrition might happen from villages that have fewer nongovernment development programs. These findings imply that attrition may be associated with the community welfare characteristics. To investigate further, we modeled a probit regression with attrition as a function of the socioeconomic characteristics, which is certainly a better predictor 
of attrition than the comparison of means. Findings reported in Table A1.4 show that none of the household or village-level characteristics are associated with attrition-effects of all regressors are statistically insignificant.

61. We also examine the association of attrition with the treatment eligibility (age cohorts). The eligibility is $67.7 \%$ overall, $43.6 \%$ among attrited, and $70 \%$ among those who stayed across the rounds. That is, ineligible individuals disproportionately dropped out over time. This is not surprising as ineligible individuals were older (on an average by 10 years), and hence, more likely to be married and employed, which may have made them move farther away from their original locations, and thus made them more untraceable during the follow-up surveys. That said, we compared the socioeconomic characteristics of the eligible and ineligible girls among the attrited girls, and we did not find any significant variations. Moreover, we re-estimated the aforementioned probit regressionthis time with cohort as an additional regressor. Again, after controlling for eligibility, we did not find any statistically significant effects of the household and community characteristics on attrition (results not reported here). Thus, we conclude that for the purpose of the analysis of this study, individual attrition can be considered random, and thus, is not expected to bias the estimated impacts of the FSSAP.

\section{Baseline Balancing Test}

62. The purpose of testing the balance of the baseline data is to investigate how close the sample data mimics a randomized sample. In a randomized sample, at least in theory, the treatment and control samples are statistically equivalent. That is, the average characteristics of the two samples are same, and in addition, their average characteristics is also same as that of the population from which the samples are drawn. Consequently, it is expected that the observed differences in the outcomes over time would be because of the intervention and intervention only. Randomized sampling also ensures that the intervention is exogenously given.

63. As mentioned in section III, the data used in this study came from a study meant to examine microcredit programs in Bangladesh, and not to investigate FSSAP program per se. However, the richness of the data makes it suitable for the study of FSSAP impacts. True, the data was not based on randomized assignment, but since eligibility to participate in the FSSAP was based on a girl's age, an exogenous criteria (that is, girls did not self-select into the program), it is expected the sample would behave like a randomized one. That is, in theory at least, the eligible and ineligible girls should be very similar in terms of household characteristics during the baseline survey. We nonetheless compared the socioeconomic characteristics (control variables) at the baseline (1991/92) between the eligible and ineligible girls, defined by age cohort.

64. As findings reported in Table A1.5 show, a few households and community characteristics do vary by the eligibility for FSSAP. For example, households of the ineligible girls had more land asset than that of the eligible girls at the baseline. On the other hand, eligible girls were from more developed villages than were the ineligible girls - the villages where eligible girls lived during the baseline survey year of 1991/92 had more schools, were more accessible and had a higher electrification rate. What this means is, even though the FSSAP eligibility was exogenously determined, there were some differences in the socioeconomic characteristics between eligible and ineligible girls, which may not be random. The implication of such differences is that these variables might have differential effects on the outcomes of interest (such as education, employment, and so on) for eligible and ineligible girls; that is, the parallel-trend assumption of DID, described earlier, would be violated. Obviously, if these effects are not controlled for, the estimated impacts of FSSAP would be biased. However, as mentioned in the estimation strategy, we used fixed-effects estimation, the generalized implementation of DID, which 
controls for household and community characteristics that may potentially affect the outcomes. Furthermore, we also showed that the assumption of parallel-trend holds based on fixed-effects estimation (section $V$, subsection 5). Thus, we conclude that while the data show some differences in baseline characteristics between eligible and ineligible girls, such differences are duly controlled for in the estimation, resulting in unbiased impacts of the FSSAP.

\section{FINDINGS}

\section{A. Intent-to-Treat Effects}

65. Intent-to-treat (ITT) analysis captures average benefits of the eligible girls over ineligible girls, regardless of actual receipt of the stipend by eligible girls. Since eligibility is based on girls' age, it is exogenous, and thus self-selection is not an issue. We implement equations (2) and (3) using an individual fixed effects model using data over four time periods, which are rigorous enough to estimate unbiased impacts of FSSAP given the exogeneity of eligibility. ${ }^{30}$ Table A1.6 reports findings from the descriptive analysis of the explanatory variables of the estimation regressions and Table A1.7 shows descriptive statistics of the outcome variables.

66. The trends in schooling outcomes of girls vis-à-vis boys as described in Table A1.7 show that both girls and boys performed well over time. For example, the average ever-schooled enrollment rate was $75.8 \%$ for girls and $79.2 \%$ for boys. However, girls progressed better since the female stipend was introduced in 1994. Thus, the ever-schooled enrollment rate was $40.9 \%$ for girls against $50.6 \%$ for boys in 1991/92, which increased to $83.9 \%$ for girls against $84.6 \%$ for boys in $1998 / 99$. The rate jumped sharply for both boys and girls during this period, but the increase registered was higher for girls than for boys during the same period. However, the secondary school level completion (passing grade 10) rate was not as satisfactory as the school enrollment rate for both boys and girls. For instance, in 2018 , only $28 \%$ of the boys and $24 \%$ of the girls completed secondary level. This shows that while the school enrollment rates of both boys and girls have increased significantly and gender disparity has disappeared in enrollment, the completion rate of secondary schooling has remained low for both boys and girls, and a little lower for girls than for boys. This indicates a crude measure of school quality at the secondary level. No wonder that the grade completion for both boys and girls has remained lowthe average schooling attainment was 4.3 years for girls against 4.7 years for boys. That is, the higher school enrollment rate has not yet translated into higher grades or secondary school completion rates. Even then, the question is if FSSAP has helped raise schooling outcomes of girls vis-à-vis boys over time, which we examine next.

67. Tables 5-8 show findings on ITT effects using the individual level fixed effects. ${ }^{31}$ We implement two models: model 1 includes cohort 1 and cohort 2 only, while model 2 includes the cohorts and the interaction terms of cohorts and the program placement variable. For each outcome in model 1 , we also carry out, but not report, Wald test for equality of cohort 1 and cohort 2 to determine if the

30 Fixed effects estimates control for unobserved determinants as long as they remain the same across panel time points. We also include a range of household- and village-level observed characteristics as control variables in the regression to control for the effects of these variables.

31 Note the fixed effects controls for the unobserved time-invariant individual ability plus household and community level heterogeneity that affects the program effects in an unobserved fashion. 
two cohorts could be combined. We find that for 12 out of 18 outcome variables of interest, the F-tests are statistically significant at the $5 \%$ significance level, implying that we can reject the null hypothesis of equality of the cohorts. So, we do not combine the two cohorts. Moreover, for model 2, we carry out the joint significance test for interaction terms, which shows that for 10 out of 18 cases the null hypothesis (the interaction terms are jointly equal to 0 ) cannot be rejected at $5 \%$ significance level. So, for consistency, we report both models, but model 1 would be considered the preferred model.

\section{Education Outcomes Among Girls}

68. Table 5 shows individual fixed effects estimates of ITT benefits for education outcomes of the girls. According to model 1, effects of cohort 1 are stronger than that of cohort 2 on cumulative enrollment and grade attainment. For example, grade attainment increased by 2.5 years for girls in cohort 1 and 1.9 years for girls in cohort $2 .{ }^{32}$ Completion of secondary schooling, however, is affected more by cohort 2 (12.1 percentage points) than by cohort 1 (10.2 percentage points). The program placement effect is statistically significant only for cumulative enrollment (model 2). Aggregate cohort effects calculated from model 2 show statistical significance for both cohorts in case of grade completed and secondary completion, but only for cohort 1 for cumulative enrollment.

\section{Women's Employment and Husband's Outcomes}

69. We do not find any incremental effect of FSSAP on women's labor force participation (Table 6), which is consistent with the descriptive statistics on employment in Table 2. As mentioned in footnote 19, this is possibly because a sizeable portion of the eligible girls, being very young compared to the ineligible girls, just entered the job market or did not start at all. ${ }^{33}$ However, when we control for being employed, we find that eligible girls are more likely to be self-employed and much more likely to be employed in the nonfarm sector (Table 6). More specifically, given that girls are employed, FSSAP increases self-employment by 22.5 percentage points among cohort 1 girls and 9.3 percentage points among cohort 2 girls (model 1). Program placement improves self-employment for cohort 2by 17 percentage points. In addition, given employment, the probability of being employed in the nonfarm sector is much higher. For example, being in cohort 1 raises the probability of being employed in the nonfarm sector by 73.2 percentage points based on model 1, while belonging to cohort 2 also raises nonfarm employment by 43.7 percentage points. ${ }^{34}$ Program placement matters only for cohort 1.

70. Females who received the stipend seem to marry men with higher education and employment than did ineligible women, nonparticipating women, or nonbeneficiaries; where again, the estimated impact is greater for cohort 1 than cohort 2. For example, the husbands of females in cohort 1 had, on average, a higher grade attainment of 0.52 year, compared to husbands of females from the control group (model 1). Moreover, FSSAP also raises husbands' overall labor force participation by 5.5 percentage points for cohort 1 , and 10 percentage points for cohort 2 . While women in cohort 2 have a higher probability of marrying self-employed men, those from both cohorts have the same higher probability than the control group women of marrying men employed in the nonfarm sector.

\footnotetext{
32 The corresponding increase in years of schooling, as estimated in Hahn et al. (2017), are 1.21 years for girls of cohort 1 and 0.66 years for cohort 2. This suggests that the estimates of Hahn et al. are probably lower bounds of the effects of FSSAP.

33 Lack of impact on labor force participation is consistent with the findings of Hahn et al. (2017).

34 Our results suggest a much higher probability of girls' working in the nonfarm sector (67-73 percentage points) than that suggested by the findings of Hahn et al. ( 6 percentage points). This means the estimates in Hahn et al. are perhaps the lower bound of FSSAP impacts on labor force participation in the nonfarm sector.
} 


\section{Table 5: Female Secondary Stipend and Assistance Program-Intent-to-Treat Effects on Education Outcomes: Girls}

\begin{tabular}{|c|c|c|c|}
\hline Outcomes & Model 1 & Model 2 & $\begin{array}{l}\text { Aggregate Cohort Effects } \\
\text { Calculated from Model } 2\end{array}$ \\
\hline \multicolumn{4}{|l|}{ Ever Enrolled } \\
\hline \multirow[t]{2}{*}{ Cohort 1} & $0.425^{* *}$ & 0.061 & $0.326^{* *}$ \\
\hline & (17.78) & $(0.65)$ & $(10.03)$ \\
\hline \multirow[t]{2}{*}{ Cohort 2} & 0.052 & -0.014 & 0.045 \\
\hline & $(1.28)$ & $(-0.36)$ & $(1.20)$ \\
\hline \multirow[t]{2}{*}{ Cohort $1 \times$ Program placement } & & $0.367^{* *}$ & \\
\hline & & $(3.85)$ & \\
\hline \multirow[t]{2}{*}{ Cohort $2 \times$ Program placement } & & 0.082 & \\
\hline & & $(1.51)$ & \\
\hline \multicolumn{4}{|l|}{ Grade Completed (years) } \\
\hline \multirow[t]{2}{*}{ Cohort 1} & $2.453^{* *}$ & $2.056^{* *}$ & $2.347^{* *}$ \\
\hline & $(8.19)$ & $(2.26)$ & $(6.36)$ \\
\hline \multirow[t]{2}{*}{ Cohort 2} & $1.861^{* *}$ & $1.968^{* *}$ & $1.874^{* *}$ \\
\hline & $(4.74)$ & $(4.13)$ & $(4.90)$ \\
\hline \multirow[t]{2}{*}{ Cohort $1 \times$ Program placement } & & 0.402 & \\
\hline & & $(0.45)$ & \\
\hline \multirow[t]{2}{*}{ Cohort $2 \times$ Program placement } & & -0.130 & \\
\hline & & $(-0.26)$ & \\
\hline \multicolumn{4}{|l|}{ Completed Secondary Level } \\
\hline \multirow[t]{2}{*}{ Cohort 1} & $0.102^{* *}$ & $0.196^{* *}$ & $0.129^{* *}$ \\
\hline & $(5.14)$ & $(2.04)$ & $(3.88)$ \\
\hline \multirow[t]{2}{*}{ Cohort 2} & $0.121^{* *}$ & $0.087^{*}$ & $0.121^{* *}$ \\
\hline & $(4.22)$ & $(1.67)$ & $(4.41)$ \\
\hline \multirow[t]{2}{*}{ Cohort $1 \times$ Program placement } & & -0.093 & \\
\hline & & $(-1.00)$ & \\
\hline \multirow[t]{2}{*}{ Cohort $2 \times$ Program placement } & & 0.048 & \\
\hline & & $(0.77)$ & \\
\hline $\mathrm{N}$ & 1,163 & & \\
\hline
\end{tabular}

\footnotetext{
* means statistically significant at $10 \%$ level, ${ }^{* *}$ means statistically significant at $5 \%$ level.
}

Note: Figures in parentheses are t-statistics based on clustered standard errors. Regressions control for year fixed-effects, and include additional control variables at the household level (head's age, sex, and education; number of adult males and females; log of agricultural land); and village level (village infrastructure such as primary and secondary schools, paved roads, electricity, government and nongovernment food programs, and prices of consumer goods).

Sources: Bangladesh Institute of Development Studies-World Bank. 1992. Bangladesh Household Survey Data, 1991/92. Dhaka; Bangladesh Institute of Development Studies-World Bank. 1999. Bangladesh Household Survey Data, 1998/99. Dhaka; Institute for Inclusive Finance and Development and World Bank. 2011. Bangladesh Household Survey Data, 2010/11. Washington, DC; and University of Tokyo Graduate School of Public Policy. 2018. Bangladesh Household Survey Data, 2018. Tokyo. 


\section{Table 6: Female Secondary Stipend and Assistance Program-Intent-to-Treat Effects on Women's Employment and Their Husbands' Outcomes}

\begin{tabular}{|c|c|c|c|}
\hline Outcomes & Model 1 & Model 2 & $\begin{array}{l}\text { Aggregate Cohort Effects } \\
\text { Calculated from Model } 2\end{array}$ \\
\hline \multicolumn{4}{|l|}{ Women's Labor Force Participation } \\
\hline \multirow[t]{2}{*}{ Cohort 1} & -0.013 & 0.052 & 0.005 \\
\hline & $(-1.01)$ & $(0.82)$ & $(0.23)$ \\
\hline \multirow[t]{2}{*}{ Cohort 2} & -0.021 & 0.032 & -0.015 \\
\hline & $(-1.36)$ & $(0.70)$ & $(-0.84)$ \\
\hline \multirow[t]{2}{*}{ Cohort $1 \times$ Program placement } & & -0.065 & \\
\hline & & $(-1.05)$ & \\
\hline \multirow[t]{2}{*}{ Cohort $2 \times$ Program placement } & & -0.065 & \\
\hline & & $(-1.47)$ & \\
\hline \multicolumn{4}{|c|}{ Women's Self-Employment Conditional on Being Employed } \\
\hline \multirow[t]{2}{*}{ Cohort 1} & $0.225^{* *}$ & $0.245^{* *}$ & $0.228^{* *}$ \\
\hline & $(5.54)$ & $(52.65)$ & $(7.40)$ \\
\hline \multirow[t]{2}{*}{ Cohort 2} & $0.093^{* *}$ & $-0.004^{*}$ & $0.119^{* *}$ \\
\hline & $(2.28)$ & $(-1.94)$ & $(3.04)$ \\
\hline \multirow[t]{2}{*}{ Cohort $1 \times$ Program placement } & & -0.023 & \\
\hline & & $(-0.56)$ & \\
\hline \multirow[t]{2}{*}{ Cohort $2 \times$ Program placement } & & $0.170^{* *}$ & \\
\hline & & $(3.15)$ & \\
\hline \multicolumn{4}{|c|}{ Women's Nonfarm Employment Conditional on Being Employed } \\
\hline \multirow[t]{2}{*}{ Cohort 1} & $0.732^{* *}$ & $0.493^{* *}$ & $0.666^{* *}$ \\
\hline & $(68.39)$ & $(97.22)$ & $(86.92)$ \\
\hline \multirow[t]{2}{*}{ Cohort 2} & $0.437^{* *}$ & $0.406^{* *}$ & $0.459^{* *}$ \\
\hline & $(11.28)$ & $(6.02)$ & $(23.60)$ \\
\hline \multirow[t]{2}{*}{ Cohort $1 \times$ Program placement } & & $0.240^{* *}$ & \\
\hline & & $(18.12)$ & \\
\hline \multirow[t]{2}{*}{ Cohort $2 \times$ Program placement } & & 0.073 & \\
\hline & & $(1.08)$ & \\
\hline \multicolumn{4}{|c|}{ Husbands' Grade Attainment (years) } \\
\hline \multirow[t]{2}{*}{ Cohort 1} & $0.518^{*}$ & $1.167^{\text {** }}$ & $0.692^{* *}$ \\
\hline & $(1.78)$ & $(3.97)$ & $(2.53)$ \\
\hline \multirow[t]{2}{*}{ Cohort 2} & 0.298 & 0.317 & 0.299 \\
\hline & $(0.97)$ & $(0.55)$ & $(0.95)$ \\
\hline \multirow[t]{2}{*}{ Cohort $1 \times$ Program placement } & & $-0.657^{* *}$ & \\
\hline & & $(-2.80)$ & \\
\hline \multirow[t]{2}{*}{ Cohort $2 \times$ Program placement } & & -0.025 & \\
\hline & & $(-0.04)$ & \\
\hline \multicolumn{4}{|l|}{ Husbands' Labor Force Participation } \\
\hline \multirow[t]{2}{*}{ Cohort 1} & $0.055^{* *}$ & $0.171^{* *}$ & $0.086^{* *}$ \\
\hline & $(3.50)$ & $(2.45)$ & $(3.49)$ \\
\hline \multirow[t]{2}{*}{ Cohort 2} & $0.099^{* *}$ & $0.138^{* *}$ & $0.103^{* *}$ \\
\hline & $(5.09)$ & $(5.45)$ & $(5.45)$ \\
\hline \multirow[t]{2}{*}{ Cohort $1 \times$ Program placement } & & $-0.117^{*}$ & \\
\hline & & $(-1.73)$ & \\
\hline Cohort $2 \times$ Program placement & & $-0.047^{*}$ & \\
\hline & & $(-1.83)$ & \\
\hline
\end{tabular}


Table 6 continued.

\begin{tabular}{|c|c|c|c|}
\hline Outcomes & Model 1 & Model 2 & $\begin{array}{l}\text { Aggregate Cohort Effects } \\
\text { Calculated from Model } 2\end{array}$ \\
\hline \multicolumn{4}{|l|}{ Husband is Self-Employed } \\
\hline \multirow[t]{2}{*}{ Cohort 1} & -0.002 & -0.030 & -0.010 \\
\hline & $(-0.11)$ & $(-0.41)$ & $(-0.35)$ \\
\hline \multirow[t]{2}{*}{ Cohort 2} & $0.056^{*}$ & 0.001 & 0.050 \\
\hline & $(1.74)$ & $(0.02)$ & $(1.47)$ \\
\hline \multirow[t]{2}{*}{ Cohort $1 \times$ Program placement } & & 0.028 & \\
\hline & & $(0.39)$ & \\
\hline \multirow[t]{2}{*}{ Cohort $2 \times$ Program placement } & & 0.067 & \\
\hline & & $(0.95)$ & \\
\hline \multicolumn{4}{|c|}{ Husband is Employed in Nonfarm Sector } \\
\hline \multirow[t]{2}{*}{ Cohort 1} & $0.069^{* *}$ & $0.244^{* *}$ & $0.116^{* *}$ \\
\hline & $(2.89)$ & $(2.40)$ & $(3.35)$ \\
\hline \multirow[t]{2}{*}{ Cohort 2} & $0.069^{* *}$ & $0.173^{* *}$ & $0.080^{* *}$ \\
\hline & $(2.24)$ & $(5.16)$ & $(2.78)$ \\
\hline \multirow[t]{2}{*}{ Cohort $1 \times$ Program placement } & & $-0.177^{*}$ & \\
\hline & & $(-1.74)$ & \\
\hline \multirow[t]{2}{*}{ Cohort $2 \times$ Program placement } & & $-0.129^{* *}$ & \\
\hline & & $(-3.38)$ & \\
\hline $\mathrm{N}$ & 1,163 & & \\
\hline \multicolumn{4}{|c|}{ * means statistically significant at $10 \%$ level, ${ }^{* *}$ means statistically significant at $5 \%$ level. } \\
\hline \multicolumn{4}{|c|}{$\begin{array}{l}\text { Note: Figures in parentheses are t-statistics based on clustered standard errors. Regressions control for year fixed-effects, and } \\
\text { include additional control variables at the household level (head's age, sex, and education; number of adult males and females; } \\
\text { log of agricultural land); and village level (village infrastructure such as primary and secondary schools, paved roads, electricity, } \\
\text { government and nongovernment food programs, and prices of consumer goods). }\end{array}$} \\
\hline \multicolumn{4}{|c|}{$\begin{array}{l}\text { Sources: Bangladesh Institute of Development Studies-World Bank. 1992. Bangladesh Household Survey Data, 1991/92. Dhaka; } \\
\text { Bangladesh Institute of Development Studies-World Bank. 1999. Bangladesh Household Survey Data, 1998/99. Dhaka; Institute } \\
\text { for Inclusive Finance and Development and World Bank. 2011. Bangladesh Household Survey Data, 2010/11. Washington, DC; } \\
\text { and University of Tokyo Graduate School of Public Policy. 2018. Bangladesh Household Survey Data, 2018. Tokyo. }\end{array}$} \\
\hline
\end{tabular}

\section{Marital and Fertility-Related Outcomes}

71. Age at marriage increases by 1.4 years for cohort 1 girls and by 3.1 years for cohort 2 girls (Table 7). This reflects one of the stated objectives of FSSAP, which is to delay marriage. It is well established that early marriage interferes with a woman's development in a number of ways. Women who are married early have little decision-making power within the home, are more likely to drop out of school, and have lower literacy and labor force participation and income (World Bank 2017). In addition, they and their children are likely to have poorer overall health and nutritional status. Use of contraceptives is higher and total fertility is lower among the women who were exposed to FSSAP than those in the control group. More specifically, FSSAP increases women's contraceptive use by 14.5 percentage points for cohort 1 , and 11.5 percentage points for cohort 2 . In addition, being in cohort 1 and cohort 2 lowers their total fertility by 0.45 and 0.17 , respectively. Reduced fertility is not just an outcome of women's conscious decisions to have fewer children, but it also follows from getting married later, an outcome of participating in FSSAP. While higher educational attainment can be seen as a mechanism to delay marriage and increase use of contraceptives, educational attainment is an important outcome in its own right. Women were asked how many sons and daughters they desired before their first child was born. While exposure to FSSAP lowers women's preference for sons (by 0.13 for being in cohort 1), it actually increases preference for daughters (by 0.05 in cohort 1). 


\section{Table 7: Female Secondary Stipend and Assistance Program-Intent-to-Treat Effects on Women's Marital and Fertility-Related Outcomes}

\begin{tabular}{|c|c|c|c|}
\hline Outcomes & Model 1 & Model 2 & $\begin{array}{l}\text { Aggregate Cohort Effects } \\
\text { Calculated from Model } 2\end{array}$ \\
\hline \multicolumn{4}{|l|}{ Age at Marriage (years) } \\
\hline \multirow[t]{2}{*}{ Cohort 1} & $1.410^{*}$ & $2.153^{* *}$ & $1.606^{* *}$ \\
\hline & (1.91) & $(2.33)$ & $(2.15)$ \\
\hline \multirow[t]{2}{*}{ Cohort 2} & $3.121^{* *}$ & $3.394^{* *}$ & $3.149^{* *}$ \\
\hline & $(4.13)$ & $(4.08)$ & $(4.16)$ \\
\hline \multirow[t]{2}{*}{ Cohort $1 \times$ Program placement } & & -0.756 & \\
\hline & & $(-1.27)$ & \\
\hline \multirow[t]{2}{*}{ Cohort $2 \times$ Program placement } & & -0.340 & \\
\hline & & $(-0.79)$ & \\
\hline \multicolumn{4}{|l|}{ Contraceptive Use } \\
\hline \multirow[t]{2}{*}{ Cohort 1} & $0.145^{* *}$ & $0.313^{* *}$ & $0.191^{* *}$ \\
\hline & $(5.29)$ & $(3.83)$ & $(5.73)$ \\
\hline \multirow[t]{2}{*}{ Cohort 2} & $0.115^{* *}$ & $0.140^{* *}$ & $0.118^{* *}$ \\
\hline & $(3.91)$ & $(2.77)$ & $(4.00)$ \\
\hline \multirow[t]{2}{*}{ Cohort $1 \times$ Program placement } & & -0.170 & \\
\hline & & $(-2.12)$ & \\
\hline \multirow[t]{2}{*}{ Cohort $2 \times$ Program placement } & & -0.030 & \\
\hline & & $(-0.60)$ & \\
\hline \multicolumn{4}{|l|}{ Total Fertility } \\
\hline \multirow[t]{2}{*}{ Cohort 1} & $-0.451^{* *}$ & -0.090 & $-0.354^{* *}$ \\
\hline & $(-5.82)$ & $(-1.11)$ & $(-4.64)$ \\
\hline \multirow[t]{2}{*}{ Cohort 2} & $-0.165^{*}$ & 0.018 & -0.145 \\
\hline & $(-1.77)$ & $(0.15)$ & $(-1.62)$ \\
\hline \multirow[t]{2}{*}{ Cohort $1 \times$ Program placement } & & $-0.364^{* *}$ & \\
\hline & & $(-7.96)$ & \\
\hline \multirow[t]{2}{*}{ Cohort $2 \times$ Program placement } & & $-0.225^{* *}$ & \\
\hline & & $(-2.03)$ & \\
\hline \multicolumn{4}{|l|}{ Desired Number of Sons } \\
\hline \multirow[t]{2}{*}{ Cohort 1} & $-0.130^{* *}$ & -0.008 & $-0.097^{* *}$ \\
\hline & $(-2.99)$ & $(-0.17)$ & $(-2.24)$ \\
\hline \multirow[t]{2}{*}{ Cohort 2} & -0.0004 & 0.043 & 0.004 \\
\hline & $(-0.01)$ & $(0.63)$ & $(0.09)$ \\
\hline \multirow[t]{2}{*}{ Cohort $1 \times$ Program placement } & & $-0.123^{* *}$ & \\
\hline & & $(-7.18)$ & \\
\hline \multirow[t]{2}{*}{ Cohort $2 \times$ Program placement } & & -0.054 & \\
\hline & & $(-0.88)$ & \\
\hline
\end{tabular}


Table 7 continued.

\begin{tabular}{|c|c|c|c|}
\hline Outcomes & Model 1 & Model 2 & $\begin{array}{l}\text { Aggregate Cohort Effects } \\
\text { Calculated from Model } 2\end{array}$ \\
\hline \multicolumn{4}{|l|}{ Desired Number of Daughters } \\
\hline \multirow[t]{2}{*}{ Cohort 1} & $0.049^{* *}$ & 0.014 & $0.040^{* *}$ \\
\hline & $(5.34)$ & $(0.39)$ & $(3.24)$ \\
\hline \multirow[t]{2}{*}{ Cohort 2} & 0.010 & $-0.014^{*}$ & 0.008 \\
\hline & $(0.89)$ & $(-1.80)$ & $(0.74)$ \\
\hline \multirow[t]{2}{*}{ Cohort $1 \times$ Program placement } & & 0.036 & \\
\hline & & $(1.01)$ & \\
\hline \multirow[t]{2}{*}{ Cohort $2 \times$ Program placement } & & $0.030^{* *}$ & \\
\hline & & $(2.49)$ & \\
\hline $\mathrm{N}$ & 1,163 & & \\
\hline
\end{tabular}

* means statistically significant at $10 \%$ level, ${ }^{* *}$ means statistically significant at $5 \%$ level.

Note: Figures in parentheses are t-statistics based on clustered standard errors. Regressions control for year fixed-effects, and include additional control variables at the household level (head's age, sex, and education; number of adult males and females; log of agricultural land); and village level (village infrastructure such as primary and secondary schools, paved roads, electricity, government and nongovernment food programs, and prices of consumer goods).

Sources: Bangladesh Institute of Development Studies-World Bank. 1992. Bangladesh Household Survey Data, 1991/92. Dhaka; Bangladesh Institute of Development Studies-World Bank. 1999. Bangladesh Household Survey Data, 1998/99. Dhaka; Institute for Inclusive Finance and Development and World Bank. 2011. Bangladesh Household Survey Data, 2010/11. Washington, DC; and University of Tokyo Graduate School of Public Policy. 2018. Bangladesh Household Survey Data, 2018. Tokyo.

\section{Spillover Effects on Boys' Schooling}

72. Finally, we look at boys' education outcomes to capture sibling spillover effects of FSSAP. A large positive effect implies large externalities of public investments (such as programs like FSSAP) in children through their effects on siblings. Table 8 shows the effects of FSSAP on education of boys from the FSSAP-receiving households. Participation in FSSAP by girls improves boys' cumulative enrollment by up to 22.7 percentage points, grade attainment by up to 1.44 years, and secondary completion rate by up to 11 percentage points. As expected, these effects are smaller than the effects FSSAP has on the girls' outcomes. These findings show the externality of program placement designed for girls, which can benefit boys as well due to the income effects enjoyed by households receiving income transfers through girls.

\section{Checking for Robustness}

73. Since eligibility is based on an individual's actual grades (closely related to their age), which is exogenous, fixed effects estimation of ITT is not subject to endogeneity biases. Even then, we use individual and year fixed effects to check for robustness of the estimation. We also investigate the parallel trend of the control group in the absence of intervention. To implement it, we divide the control group (born between 1971 and 1979) into two groups-one by randomly selecting five birth years between 1971 and 1979, and the other for the rest of the years. We call the first group cohort 3, and then use it as an additional regressor in the ITT estimation of FSSAP on girls' outcomes. The idea is, if the assumption of parallel trend holds, the coefficients of cohort 3 will not be significantly different from zero. Findings on the estimation are shown in Table A1.8. Findings clearly show that the effect of cohort 3 is not statistically significant on any of the three education outcomes of the girls. On the other hand, the effects of cohorts 1 and 2 are statistically significant on two outcomes. Thus, the findings show that the assumption of a parallel trend for control groups holds and that the estimates of FSSAP are primarily because of cohort-based stipend policy. 


\section{Table 8: Female Secondary Stipend and Assistance Program-Intent-to-Treat Effects on Education Outcomes: Boys}

\begin{tabular}{|c|c|c|c|}
\hline Outcomes & Model 1 & Model 2 & $\begin{array}{l}\text { Aggregate Cohort Effects } \\
\text { Calculated from Model } 2\end{array}$ \\
\hline \multicolumn{4}{|l|}{ Ever Enrolled } \\
\hline \multirow[t]{2}{*}{ Cohort 1} & $0.227^{* *}$ & -0.046 & $0.162^{* *}$ \\
\hline & $(16.37)$ & $(-1.37)$ & $(12.60)$ \\
\hline \multirow[t]{2}{*}{ Cohort 2} & $-0.090^{* *}$ & $-0.066^{*}$ & $-0.081^{* *}$ \\
\hline & $(-5.47)$ & $(-1.90)$ & $(-5.64)$ \\
\hline \multirow[t]{2}{*}{ Cohort $1 \times$ Program placement } & & $0.256^{* *}$ & \\
\hline & & (7.17) & \\
\hline \multirow[t]{2}{*}{ Cohort $2 \times$ Program placement } & & -0.018 & \\
\hline & & $(-0.44)$ & \\
\hline \multicolumn{4}{|l|}{ Grade Completed (years) } \\
\hline \multirow[t]{2}{*}{ Cohort 1} & $1.437^{* *}$ & $1.216^{* *}$ & $1.230^{* *}$ \\
\hline & $(10.28)$ & $(2.27)$ & $(8.39)$ \\
\hline \multirow[t]{2}{*}{ Cohort 2} & $0.495^{* *}$ & $0.902^{* *}$ & $0.472^{* *}$ \\
\hline & $(2.94)$ & $(2.47)$ & (3.18) \\
\hline \multirow[t]{2}{*}{ Cohort $1 \times$ Program placement } & & 0.018 & \\
\hline & & $(0.03)$ & \\
\hline \multirow[t]{2}{*}{ Cohort $2 \times$ Program placement } & & -0.528 & \\
\hline & & $(-1.40)$ & \\
\hline \multicolumn{4}{|l|}{ Completed Secondary Level } \\
\hline \multirow[t]{2}{*}{ Cohort 1} & $0.113^{* *}$ & $0.358^{* *}$ & $0.146^{* *}$ \\
\hline & $(6.38)$ & $(20.53)$ & $(10.38)$ \\
\hline \multirow[t]{2}{*}{ Cohort 2} & $0.052^{* *}$ & $0.151^{*}$ & $0.054^{* *}$ \\
\hline & $(2.02)$ & $(1.98)$ & $(2.26)$ \\
\hline \multirow[t]{2}{*}{ Cohort $1 \times$ Program placement } & & $-0.260^{* *}$ & \\
\hline & & $(-13.25)$ & \\
\hline \multirow[t]{2}{*}{ Cohort $2 \times$ Program placement } & & -0.119 & \\
\hline & & $(-1.53)$ & \\
\hline $\mathrm{N}$ & 1,717 & & \\
\hline
\end{tabular}

${ }^{*}$ means statistically significant at $10 \%$ level, ${ }^{* *}$ means statistically significant at $5 \%$ level.

Note: Figures in parentheses are t-statistics based on clustered standard errors. Regressions control for year fixed-effects, and include additional control variables at the household level (head's age, sex, and education; number of adult males and females; log of agricultural land); and village level (village infrastructure such as primary and secondary schools, paved roads, electricity, government and nongovernment food programs, and prices of consumer goods).

Sources: Bangladesh Institute of Development Studies-World Bank. 1992. Bangladesh Household Survey Data, 1991/92. Dhaka; Bangladesh Institute of Development Studies-World Bank. 1999. Bangladesh Household Survey Data, 1998/99. Dhaka; Institute for Inclusive Finance and Development and World Bank. 2011. Bangladesh Household Survey Data, 2010/11. Washington, DC; and University of Tokyo Graduate School of Public Policy. 2018. Bangladesh Household Survey Data, 2018. Tokyo. 


\section{B. Treatment-on-the-Treated Effects}

74. As discussed in the last section, eligibility does not guarantee participation-not all eligible girls participated in the FSSAP, for different reasons. In this subsection, we estimate the effects of girls' actual participation in FSSAP on the outcomes of interest. Since such participation may be endogenous, a simple fixed effects method is not enough to control for endogeneity (in this case, the effects of time-varying unobserved factors may matter). Thus, we implement IV regression with individual-level fixed effects to control for such endogeneity, which is due mostly to self-selection. ${ }^{35}$ Findings on the first-stage equation (determinants of endogenous participation) are shown in Table A1.9 and the effects of endogenous participation in FSSAP on the outcomes of interest are reported in Tables 9-12. For comparison, we also report findings from simple fixed effects estimates. ${ }^{36}$

\section{Education Outcomes for Girls}

75. Findings vary to some extent between the two implementations (Table 9). The effect on grade completion is higher for fixed effects instrumental variable method (FE-IV) (3.18) than for simple fixed effects (2.89). On the other hand, girls' secondary completion rate also goes up because of FSSAP participation by as much as 6.2 percentage points based on simple fixed effects and 5.2 percentage points based on FE-IV. These findings are in line with those from intent-to-treat analysis and provide stronger evidence that FSSAP was successful in achieving its primary objectives-raising girls' enrollment and their secondary completion rates.

Table 9: Female Secondary Stipend and Assistance Program-Treatment-on-the-Treated Effects on Women's Education Outcomes

\begin{tabular}{|c|c|c|c|}
\hline Outcomes & $\mathrm{FE}$ & FE-IV & Endogeneity Test Statistics \\
\hline \multirow[t]{2}{*}{ Grade completed } & $2.886^{* *}$ & $3.182^{* *}$ & $x^{2}(3)=22.338, p=0.0001$ \\
\hline & $(18.44)$ & $(13.24)$ & \\
\hline \multirow[t]{2}{*}{ Completed secondary level } & $0.062^{* *}$ & $0.052^{* *}$ & $x^{2}(3)=7.667, p=0.053$ \\
\hline & $(2.83)$ & $(2.00)$ & \\
\hline $\mathrm{N}$ & $N=1,163$ & $N=1,163$ & \\
\hline \multicolumn{4}{|c|}{ ** means statistically significant at $5 \%$ level. } \\
\hline \multicolumn{4}{|c|}{$F E=$ fixed effects, $F E-I V=$ fixed-effects instrumental variables. } \\
\hline \multicolumn{4}{|c|}{$\begin{array}{l}\text { Note: Figures in parentheses are t-statistics based on clustered standard errors. Regressions control for year fixed-effects, and } \\
\text { include additional control variables at the household level (head's age, sex, and education; number of adult males and females; } \\
\text { log of agricultural land); and village level (village infrastructure such as primary and secondary schools, paved roads, electricity, } \\
\text { government and nongovernment food programs, and prices of consumer goods). }\end{array}$} \\
\hline \multicolumn{4}{|c|}{$\begin{array}{l}\text { Sources: Bangladesh Institute of Development Studies-World Bank. 1992. Bangladesh Household Survey Data, 1991/92. Dhaka; } \\
\text { Bangladesh Institute of Development Studies-World Bank. 1999. Bangladesh Household Survey Data, 1998/99. Dhaka; Institute } \\
\text { for Inclusive Finance and Development and World Bank. 2011. Bangladesh Household Survey Data, 2010/11. Washington, DC; } \\
\text { and University of Tokyo Graduate School of Public Policy. 2018. Bangladesh Household Survey Data, 2018. Tokyo. }\end{array}$} \\
\hline
\end{tabular}

35 In IV implementation, the endogenous participation in FSSAP is instrumented with exogenous age-specific eligibility, discussed earlier. Girls can be eligible for being in cohort 1 or 2, and accordingly, we use two eligible criteria. See Table A1.9 for the first-stage regression outputs, which show a statistically significant relationship between endogenous participation and the instruments (exogenous eligibility of the girls).

36 Fixed effects estimates average impacts whereas FE-IV estimates marginal impacts. Average impact is usually higher than marginal impact; however, the former can be equal to or less than the latter depending on the location of the impact distribution curve. 


\section{Women's Employment and Husbands' Outcomes}

76. The impacts of FSSAP participation on women's employment and husbands' outcomes are reported in Table 10. Neither simple fixed effects model nor FE-IV show any statistically significant impacts of FSSAP on women's labor force participation. As for other outcomes, between simple fixed effects and FE-IV implementations, the latter has higher impacts on both women's employment outcomes and husbands' outcomes. For example, given that women are employed, the probability of self-employment goes up 11 percentage points based on simple fixed effects and 19 percentage points based on FE-IV. On the other hand, grade attainment of women's husbands due to FSSAP participation is 1.28 years higher based on simple fixed effects and 2.73 years based on FE-IV. Finally, husbands' employment and employment in the nonfarm sector increases because of FSSAP participation, while their engagement in self-employment is not affected by FSSAP. These findings show unambiguously that, besides the immediate (or short-term) outcomes for women, intermediate outcomes also improve from participation in FSSAP.

Table 10: Female Secondary Stipend and Assistance Program-Treatment-on-the-Treated Effects on Employment and Spouse-Related Outcomes

\begin{tabular}{lccc}
\hline Outcomes & FE & FE-IV & Endogeneity Test Statistics \\
\hline Labor force participation & -0.015 & -0.052 & $x^{2}(1)=0.900, p=0.343$ \\
\cline { 2 - 3 } & $(-1.37)$ & $(-1.53)$ & \\
\hline If self-employed, conditional & $0.111^{* *}$ & $0.194^{*}$ & $x^{2}(2)=0.685, p=0.758$ \\
on being employed & $(3.27)$ & $(1.93)$ & \\
\hline Employed in nonfarm sector, conditional & $0.471^{* *}$ & $0.579^{* *}$ & $x^{2}(2)=0.613, p=0.979$ \\
\cline { 2 - 3 } on being employed & $(60.08)$ & $(3.30)$ & \\
\hline Husband's grade completed & $1.284^{* *}$ & $2.727^{* *}$ & $x^{2}(1)=1.024, p=0.312$ \\
\hline Husband's labor force participation & $(6.19)$ & $(3.12)$ & $x^{2}(1)=0.967, p=0.033$ \\
\hline Husband is self-employed & $0.133^{* *}$ & $0.355^{* *}$ & \\
\hline Husband is employed in nonfarm sector & $(6.40)$ & $(5.46)$ & $x^{2}(1)=0.018, p=0.893$ \\
\cline { 2 - 4 } & 0.030 & 0.017 & \\
\hline $\mathrm{N}$ & $(1.06)$ & $(0.16)$ & $x^{2}(1)=5.541, p=0.019$ \\
\hline
\end{tabular}

${ }^{*}$ means statistically significant at $10 \%$ level, ${ }^{* *}$ means statistically significant at $5 \%$ level.

$\mathrm{FE}=$ fixed effects, $\mathrm{FE}-\mathrm{IV}=$ fixed-effects instrumental variables.

Note: Figures in parentheses are t-statistics based on clustered standard errors. Regressions control for year fixed-effects, and include additional control variables at the household level (head's age, sex, and education; number of adult males and females; log of agricultural land); and village level (village infrastructure such as primary and secondary schools, paved roads, electricity, government and nongovernment food programs, and prices of consumer goods).

Sources: Bangladesh Institute of Development Studies-World Bank. 1992. Bangladesh Household Survey Data, 1991/92. Dhaka; Bangladesh Institute of Development Studies-World Bank. 1999. Bangladesh Household Survey Data, 1998/99. Dhaka; Institute for Inclusive Finance and Development and World Bank. 2011. Bangladesh Household Survey Data, 2010/11. Washington, DC; and University of Tokyo Graduate School of Public Policy. 2018. Bangladesh Household Survey Data, 2018. Tokyo. 


\section{Marital and Fertility-Related Outcomes}

77. Effects of FSSAP on marital and fertility outcomes based on FE-IV are again found to be stronger than those based on simple fixed effects (Table 11). Women who participated in the FSSAP marry at an age 0.9 year higher based on simple fixed effects and 3.2 years higher based on FE-IV than women in the counterpart control group. This is the fulfillment of another important objective of the FFSAP - delaying the age of marriage. A delay in marriage, with women unburdened of marital responsibilities and chores, especially those associated with child-rearing, is often said to help women advance their careers and become independent, particularly in developing countries. Women's contraceptive use increases by 24 percentage points and total fertility decreases by 0.76 as a result of FSSAP participation, according to FE-IV estimation. Participation in FSSAP lowers the desired number of sons by 0.06 (based on simple fixed effects) and increases the desired number of daughters by 0.22. Preference for boys in developing countries indicates a need for security, especially for women, because it is sons, not daughters, who are expected to care for aging parents as per the social norm. The reduced demand for boys then shows that participation in FSSAP makes women more independent in the long run, so much so that they do not want to depend on adult sons in old age.

Table 11: Female Secondary Stipend and Assistance Program-Treatment-on-the-Treated Effects on Marriage and Fertility-Related Outcomes

\begin{tabular}{|c|c|c|c|}
\hline Outcomes & Simple FE & FE-IV & Endogeneity Test Statistics \\
\hline \multirow[t]{2}{*}{ Age at marriage (years) } & $0.913^{* *}$ & $3.165^{* *}$ & $x^{2}(3)=28.302, p=0.000$ \\
\hline & $(2.52)$ & $(2.08)$ & \\
\hline \multirow[t]{2}{*}{ Use of contraceptives } & $0.055^{* *}$ & $0.243^{* *}$ & $x^{2}(1)=0.578, p=0.447$ \\
\hline & $(2.59)$ & $(5.64)$ & \\
\hline \multirow[t]{2}{*}{ Total fertility } & $-0.274^{* *}$ & $-0.760^{* *}$ & $x^{2}(1)=38.634, p=0.000$ \\
\hline & $(-6.25)$ & $(-6.99)$ & \\
\hline \multirow{2}{*}{$\begin{array}{l}\text { Preferred number of sons before first } \\
\text { child was born }\end{array}$} & $-0.057^{* *}$ & -0.143 & $x^{2}(1)=0.000, p=0.993$ \\
\hline & $(-2.33)$ & $(-1.38)$ & \\
\hline \multirow{2}{*}{$\begin{array}{l}\text { Preferred number of daughters } \\
\text { before first child was born }\end{array}$} & 0.011 & $0.224^{* *}$ & $x^{2}(1)=0.020, p=0.889$ \\
\hline & $(0.96)$ & $(5.70)$ & \\
\hline $\mathrm{N}$ & $N=1,163$ & $N=1,163$ & \\
\hline \multicolumn{4}{|c|}{ ** means statistically significant at $5 \%$ level. } \\
\hline \multicolumn{4}{|c|}{$F E=$ fixed effects, $F E-I V=$ fixed-effects instrumental variables. } \\
\hline \multicolumn{4}{|c|}{$\begin{array}{l}\text { Note: Figures in parentheses are t-statistics based on clustered standard errors. Regressions control for year fixed-effects, and } \\
\text { include additional control variables at the household level (head's age, sex, and education; number of adult males and females; } \\
\text { log of agricultural land); and village level (village infrastructure such as primary and secondary schools, paved roads, electricity, } \\
\text { government and nongovernment food programs, and prices of consumer goods). }\end{array}$} \\
\hline \multicolumn{4}{|c|}{$\begin{array}{l}\text { Sources: Bangladesh Institute of Development Studies-World Bank. 1992. Bangladesh Household Survey Data, 1991/92. Dhaka; } \\
\text { Bangladesh Institute of Development Studies-World Bank. 1999. Bangladesh Household Survey Data, 1998/99. Dhaka; Institute } \\
\text { for Inclusive Finance and Development and World Bank. 2011. Bangladesh Household Survey Data, 2010/11. Washington, DC; } \\
\text { and University of Tokyo Graduate School of Public Policy. 2018. Bangladesh Household Survey Data, 2018. Tokyo. }\end{array}$} \\
\hline
\end{tabular}




\section{Spillover Effects on Boys' Schooling}

78. Finally, the spillover effects of FSSAP participation on boys' education outcomes are mixedsubstantial positive impacts on grade attainment, but no statistically significant impacts on secondary completion (Table 12). We can conclude that the beneficial effects of FSSAP (both exogenous eligibility and endogenous participation) on a range of women's and their husbands' outcomes are robust. $^{37}$

Table 12: Female Secondary Stipend and Assistance Program-Treatment-on-the-Treated Effects on Education Outcomes: Boys

\begin{tabular}{|c|c|c|c|}
\hline Outcomes & Simple FE & FE-IV & Endogeneity Test Statistics \\
\hline \multirow[t]{2}{*}{ Grade completed } & $0.724^{* *}$ & $5.704^{* *}$ & $x^{2}(5)=44.705, p=0.000$ \\
\hline & $(3.28)$ & $(5.23)$ & \\
\hline \multirow[t]{2}{*}{ Completed secondary level } & 0.022 & 0.048 & $x^{2}(5)=36.468, p=0.000$ \\
\hline & $(0.78)$ & $(0.55)$ & \\
\hline $\mathrm{N}$ & $\mathrm{N}=1,717$ & $N=1,717$ & \\
\hline \multicolumn{4}{|c|}{ ** means statistically significant at $5 \%$ level. } \\
\hline \multicolumn{4}{|c|}{$F E=$ fixed effects, $F E-I V$ = fixed-effects instrumental variables. } \\
\hline \multicolumn{4}{|c|}{$\begin{array}{l}\text { Note: Figures in parentheses are t-statistics based on clustered standard errors. Regressions control for year fixed-effects, and } \\
\text { include additional control variables at the household level (head's age, sex, and education; number of adult males and females; } \\
\text { log of agricultural land); and village level (village infrastructure such as primary and secondary schools, paved roads, electricity, } \\
\text { government and nongovernment food programs, and prices of consumer goods). }\end{array}$} \\
\hline \multicolumn{4}{|c|}{$\begin{array}{l}\text { Sources: Bangladesh Institute of Development Studies-World Bank. 1992. Bangladesh Household Survey Data, 1991/92. Dhaka; } \\
\text { Bangladesh Institute of Development Studies-World Bank. 1999. Bangladesh Household Survey Data, 1998/99. Dhaka; Institute } \\
\text { for Inclusive Finance and Development and World Bank. 2011. Bangladesh Household Survey Data, 2010/11. Washington, DC; } \\
\text { and University of Tokyo Graduate School of Public Policy. 2018. Bangladesh Household Survey Data, 2018. Tokyo. }\end{array}$} \\
\hline
\end{tabular}

\section{Does Differential Exposure Matter?}

79. Eligible girls could have been exposed to FSSAP for 1-5 years. ${ }^{38}$ So, it is reasonable that the differential exposure to FSSAP would have differential effects on the outcomes of interest. Therefore, we estimate the effects of the FSSAP program duration on the outcomes, again using both simple fixed effects and FE-IV. Findings in Tables 13-16 are in line with those on the effects of FSSAP participation. For each additional year of participation in FSSAP, grade attainment goes up by about a year and the secondary completion rate by 2.1 percentage points - all according to FE-IV estimation (Table 13). ${ }^{39}$

37 We also checked for FSSAP benefits on outcomes of children of the women, especially education outcomes such as current enrollment and grade attainment. However, we found that a large share of the children of the participating women are not old enough to start schooling or be in higher grades; therefore, are not comparable to the children of the women in the control group. To assess such benefits accurately, a later study (say in 2025) would be more suitable.

38 This variation was not only because the program was introduced to different grades in different years, as mentioned earlier, but also for other reasons. For example, some girls dropped out of the program because they did not perform well enough as required by the program; some discontinued study because they got married; and for some girls, especially those from wealthy households, the FSSAP financial incentive was not enough to persuade families to send girls to school.

39 Note that the estimates reported in Tables 13-16 are marginal effects of duration models compared to the average as reported in Tables 5-8 with the intent-to-treat models. 
Table 13: Female Secondary Stipend and Assistance Program-Treatment-on-the-Treated Effects of Participation Duration (Years) on Education Outcomes

\begin{tabular}{|c|c|c|c|}
\hline Outcomes & FE & FE-IV & Endogeneity Test Statistics \\
\hline \multirow[t]{2}{*}{ Grade completed } & $0.758^{* *}$ & $0.998^{* *}$ & $x^{2}(3)=20.612, p=0.000$ \\
\hline & $(19.09)$ & $(10.71)$ & \\
\hline \multirow[t]{2}{*}{ Completed secondary level } & $0.026^{* *}$ & $0.021^{* *}$ & $x^{2}(3)=8.197, p=0.042$ \\
\hline & $(4.61)$ & $(2.47)$ & \\
\hline $\mathrm{N}$ & $N=1,163$ & $N=1,163$ & \\
\hline \multicolumn{4}{|c|}{ ** means statistically significant at $5 \%$ level. } \\
\hline \multicolumn{4}{|c|}{$\mathrm{FE}=$ fixed effects, $\mathrm{FE}-\mathrm{IV}=$ fixed-effects instrumental variables. } \\
\hline \multicolumn{4}{|c|}{$\begin{array}{l}\text { Note: Figures in parentheses are t-statistics based on clustered standard errors. Regressions control for year fixed-effects, and } \\
\text { include additional control variables at the household level (head's age, sex, and education; number of adult males and females; } \\
\text { log of agricultural land); and village level (village infrastructure such as primary and secondary schools, paved roads, electricity, } \\
\text { government and nongovernment food programs, and prices of consumer goods). }\end{array}$} \\
\hline \multicolumn{4}{|c|}{$\begin{array}{l}\text { Sources: Bangladesh Institute of Development Studies-World Bank. 1992. Bangladesh Household Survey Data, 1991/92. Dhaka; } \\
\text { Bangladesh Institute of Development Studies-World Bank. 1999. Bangladesh Household Survey Data, 1998/99. Dhaka; Institute } \\
\text { for Inclusive Finance and Development and World Bank. 2011. Bangladesh Household Survey Data, 2010/11. Washington, DC; } \\
\text { and University of Tokyo Graduate School of Public Policy. 2018. Bangladesh Household Survey Data, 2018. Tokyo. }\end{array}$} \\
\hline
\end{tabular}

80. As Table 14 shows, FSSAP program duration does not show any impact on women's labor force participation based on FE-IV estimation, similar to the findings on treatment effects shown in Table $10 .{ }^{40}$ However, their self-employment can rise by 7.2 percentage points, and employment in the nonfarm sector by 19.5 percentage points, for each additional year they received financial benefits from FSSAP (FE-IV estimation). Impacts on FSSAP program duration on spousal outcomes are consistent with that of program participation. Both husbands' labor force participation and their employment in the nonfarm sector increase by 12 percentage points due to 1 year of exposure of their wives to FSSAP, according to the FE-IV estimation.

81. Each incremental year of exposure to FSSAP increases women's age of marriage up to 1.2 years. Fertility outcomes show that each additional year of FSSAP stipend increases women's contraceptive use by 8.2 percentage points and decreases total fertility by 0.24 , based on FE-IV (Table 15). Also, in line with participation impacts, women's son-preference goes down and daughter-preference goes up for an additional year of FSSAP participation. Finally, spillover effects on boys' education outcomes are also positive for FSSAP duration (Table 16). So, we can conclude that participation in the program is important to enhancing women's immediate, intermediate, and long-term welfare, and differential exposure to FSSAP matters too.

40 However, simple fixed effects show a negative effect, although very low, of the FSSAP program on women's employment, which is a bit surprising. This may be a case where incremental effects of exposure are not captured properly. 
Table 14: Female Secondary Stipend and Assistance Program - Treatment-on-the-Treated Effects of Participation Duration (Years) on Women's Employment and Husband's Outcomes

\begin{tabular}{lccc}
\hline Outcomes & FE & FE-IV & Endogeneity Test Statistics \\
\hline Labor force participation rate & $-0.005^{*}$ & -0.017 & $x^{2}(1)=1.132, p=0.287$ \\
\cline { 2 - 3 } & $(-1.88)$ & $(-1.53)$ & \\
\hline Self-employed, conditional & $0.037^{* *}$ & $0.072^{* *}$ & $x^{2}(2)=0.633, p=0.915$ \\
on being employed & $(3.23)$ & $(2.00)$ & \\
\hline Employed in nonfarm sector, conditional & $0.125^{* *}$ & $0.195^{* *}$ & $x^{2}(2)=0.370, p=1.986$ \\
\cline { 2 - 3 } on being employed & $(13.91)$ & $(2.65)$ & \\
\hline Husband's grade completed & $0.356^{* *}$ & $0.854^{* *}$ & $x^{2}(1)=0.977, p=0.329$ \\
\cline { 2 - 3 } & $(6.56)$ & $(3.24)$ & $x^{2}(1)=2.605, p=0.017$ \\
\hline Husband's labor force participation rate & $0.029^{* *}$ & $0.120^{* *}$ & $x^{2}(1)=0.280, p=1.165$ \\
\hline Husband is self-employed & $(7.53)$ & $(5.87)$ & \\
\hline Husband is employed in nonfarm sector & -0.001 & 0.013 & $x^{2}(1)=12.027, p=0.001$ \\
\cline { 2 - 3 } & $(-0.14)$ & $(0.41)$ & \\
\hline $\mathrm{N}$ & $0.029^{* *}$ & $0.117^{* *}$ & $(4.23)$ \\
\hline
\end{tabular}

${ }^{*}$ means statistically significant at $10 \%$ level, ${ }^{* *}$ means statistically significant at $5 \%$ level.

$\mathrm{FE}=$ fixed effects, $\mathrm{FE}-\mathrm{IV}=$ fixed-effects instrumental variables.

Note: Figures in parentheses are t-statistics based on clustered standard errors. Regressions control for year fixed-effects, and include additional control variables at the household level (head's age, sex, and education; number of adult males and females; log of agricultural land); and village level (village infrastructure such as primary and secondary schools, paved roads, electricity, government and nongovernment food programs, and prices of consumer goods).

Sources: Bangladesh Institute of Development Studies-World Bank. 1992. Bangladesh Household Survey Data, 1991/92. Dhaka; Bangladesh Institute of Development Studies-World Bank. 1999. Bangladesh Household Survey Data, 1998/99. Dhaka; Institute for Inclusive Finance and Development and World Bank. 2011. Bangladesh Household Survey Data, 2010/11. Washington, DC; and University of Tokyo Graduate School of Public Policy. 2018. Bangladesh Household Survey Data, 2018. Tokyo.

\section{Table 15: Female Secondary Stipend and Assistance Program - Treatment-on-the-Treated Effects of Participation Duration (Years) on Marriage and Fertility-Related Outcomes}

\begin{tabular}{|c|c|c|c|}
\hline Outcomes & FE & FE-IV & Endogeneity Test Statistics \\
\hline \multirow[t]{2}{*}{ Age at marriage (years) } & $0.238^{* *}$ & $1.174^{* *}$ & $x^{2}(1)=26.326, p=0.000$ \\
\hline & $(2.42)$ & $(2.20)$ & \\
\hline \multirow[t]{2}{*}{ Use of contraceptives } & 0.008 & $0.082^{* *}$ & $x^{2}(1)=16.734, p=0.001$ \\
\hline & (1.51) & $(5.36)$ & \\
\hline \multirow[t]{2}{*}{ Total fertility } & $-0.073^{* *}$ & $-0.242^{* *}$ & $x^{2}(3)=32.848, p=0.000$ \\
\hline & $(-6.48)$ & $(-5.88)$ & \\
\hline \multirow{2}{*}{$\begin{array}{l}\text { Preferred number of sons before first child } \\
\text { was born }\end{array}$} & $-0.018^{* *}$ & 0.001 & $x^{2}(1)=0.530, p=0.467$ \\
\hline & $(-2.85)$ & $(0.04)$ & \\
\hline \multirow{2}{*}{$\begin{array}{l}\text { Preferred number of daughters before first } \\
\text { child was born }\end{array}$} & 0.004 & $0.067^{* *}$ & $x^{2}(1)=0.233, p=0.625$ \\
\hline & $(1.28)$ & $(5.45)$ & \\
\hline $\mathrm{N}$ & $\mathrm{N}=1,163$ & $N=1,163$ & \\
\hline \multicolumn{4}{|l|}{ ** means statistically significant at $5 \%$ level. } \\
\hline \multicolumn{4}{|c|}{$F E=$ fixed effects, $F E-I V=$ fixed-effects instrumental variables. } \\
\hline \multicolumn{4}{|c|}{$\begin{array}{l}\text { Note: Figures in parentheses are t-statistics based on clustered standard errors. Regressions control for year fixed-effects, and } \\
\text { include additional control variables at the household level (head's age, sex, and education; number of adult males and females; } \\
\text { log of agricultural land); and village level (village infrastructure such as primary and secondary schools, paved roads, electricity, } \\
\text { government and nongovernment food programs, and prices of consumer goods). }\end{array}$} \\
\hline \multicolumn{4}{|c|}{$\begin{array}{l}\text { Sources: Bangladesh Institute of Development Studies-World Bank. 1992. Bangladesh Household Survey Data, 1991/92. Dhaka; } \\
\text { Bangladesh Institute of Development Studies-World Bank. 1999. Bangladesh Household Survey Data, 1998/99. Dhaka; Institute } \\
\text { for Inclusive Finance and Development and World Bank. 2011. Bangladesh Household Survey Data, 2010/11. Washington, DC; } \\
\text { and University of Tokyo Graduate School of Public Policy. 2018. Bangladesh Household Survey Data, 2018. Tokyo. }\end{array}$} \\
\hline
\end{tabular}


Table 16: Female Secondary Stipend and Assistance Program-Treatment-on-the-Treated Effects of Participation Duration (Years) on Boys' Education Outcomes

\begin{tabular}{lccc}
\hline Outcomes & FE & FE-IV & Endogeneity Test Statistics \\
\hline Grade enrolled & $0.192^{* *}$ & $0.664^{* *}$ & $x^{2}(1)=1.251, p=0.264$ \\
\cline { 2 - 3 } & $(3.05)$ & $(4.88)$ & $x^{2}(1)=4.868, p=0.027$ \\
\hline Completed secondary level & 0.007 & $0.025^{* *}$ & $(2.79)$ \\
\hline $\mathrm{N}$ & $\mathrm{N}=1,717$ & $\mathrm{~N}=1,717$ & \\
\hline \multirow{2}{*}{ ** means statistically significant at 5\% level. } & & \\
FE = fixed effects, FE-IV = fixed-effects instrumental variables. & \\
Note: Figures in parentheses are t-statistics based on clustered standard errors. Regressions control for year fixed-effects, and \\
include additional control variables at the household level (head's age, sex, and education; number of adult males and females; \\
log of agricultural land); and village level (village infrastructure such as primary and secondary schools, paved roads, electricity, \\
government and nongovernment food programs, and prices of consumer goods). \\
Sources: Bangladesh Institute of Development Studies-World Bank. 1992. Bangladesh Household Survey Data, 1991/92. Dhaka; \\
Bangladesh Institute of Development Studies-World Bank. 1999. Bangladesh Household Survey Data, 1998/99. Dhaka; Institute \\
for Inclusive Finance and Development and World Bank. 2011. Bangladesh Household Survey Data, 2010/11. Washington, DC; \\
and University of Tokyo Graduate School of Public Policy. 2018. Bangladesh Household Survey Data, 2018. Tokyo.
\end{tabular}

\section{Income Effects of Female Education}

82. The study of FSSAP allows us to examine the income effects of education-a critically important exercise on the contribution of education. In particular, we would like to know if schooling, especially at the secondary level, matters to women's earning. It is important to know whether families invest in girls' schooling because of the FSSAP only, or there are income returns to female education. To assess impacts of education on women's income, we use an outcome equation similar to equation (2), with education included as an additional regressor. We estimated two models: one with education only, and the other with education and cohort variables. Model 2 is meant to show if exposure to FSSAP (represented by cohorts) makes any difference in the income effects of education. Education is captured in two ways (specifications) within each model-one by grade completed (or schooling years), and the other by milestone completion (primary completion and secondary completion). Finally, we estimated each model using both cross-sectional data of 2018 survey round and panel data of all four rounds. ${ }^{41}$

83. Table 17 shows that first and foremost, education has substantial impacts on women's earnings, and results from cross-sectional estimation vary from those from panel estimation. In addition, findings vary across models, especially within panel estimation. Each additional year of grade completion increases women's income by $9 \%$ based on model 1 , and the effect is 1 percentage point higher when FSSAP is factored in the specification (model 2 panel estimation). Education effects are much higher when women complete secondary education. For example, cross-sectional estimates, regardless of the models, show that a $61 \%$ rise in income can be attributed to secondary completion. While income growth is less in panel estimation, it is 7 percentage points higher when cohorts are accounted for in the model (model 2). ${ }^{42}$ More specifically, income effect due to secondary completion jumps from $41 \%$ to $48 \%$ with exposure to FSSAP. Finally, completion of primary level education does not make any difference in women's income.

41 For cross-sectional estimation, 2018 data are used, because it is the last survey round and, consequently, has the highest likelihood that all individuals, including FSSAP participants, are employed by this time.

42 Cross-sectional effects are higher than those in panel estimation perhaps because the former does not control for the unobserved individual ability. Hence, panel data analysis is a preferred model. 
84. Findings thus clearly substantiate the large body of literature showing that education matters to income; and what is more relevant to this study is women's exposure to FSSAP sharpens the income effects of education. ${ }^{43}$

\section{Table 17: Female Secondary Stipend and Assistance Program- Income Effects of Education and the Program}

\begin{tabular}{|c|c|c|c|c|}
\hline \multirow[b]{2}{*}{ Education and Cohort Variables } & \multicolumn{2}{|c|}{$\begin{array}{c}\text { Cross Sectional Estimation } \\
\text { (village FE) }\end{array}$} & \multicolumn{2}{|c|}{$\begin{array}{l}\text { Panel Estimation } \\
\text { (individual FE) }\end{array}$} \\
\hline & Model 1 & Model 2 & Model 1 & Model 2 \\
\hline \multicolumn{5}{|l|}{ Specification 1} \\
\hline Grade completed & $\begin{array}{l}0.092^{* *} \\
(2.99)\end{array}$ & $\begin{array}{l}0.093^{* *} \\
(3.02)\end{array}$ & $\begin{array}{l}0.092^{* *} \\
(2.75)\end{array}$ & $\begin{array}{l}0.100^{* *} \\
(2.85)\end{array}$ \\
\hline Cohort 1 & & $\begin{array}{r}0.145 \\
(0.28) \\
\end{array}$ & & $\begin{array}{c}0.092 \\
(0.39)\end{array}$ \\
\hline Cohort 2 & & $\begin{array}{r}0.337 \\
(0.76) \\
\end{array}$ & & $\begin{array}{l}-0.108 \\
(-0.61)\end{array}$ \\
\hline $\mathrm{R}^{2}$ & 0.074 & 0.075 & 0.133 & 0.140 \\
\hline \multicolumn{5}{|l|}{ Specification 2} \\
\hline Primary completed & $\begin{array}{r}0.199 \\
(0.99) \\
\end{array}$ & $\begin{array}{l}0.202 \\
(1.00)\end{array}$ & $\begin{array}{l}-0.046 \\
(-0.39)\end{array}$ & $\begin{array}{l}-0.003 \\
(-0.02)\end{array}$ \\
\hline Secondary completed & $\begin{array}{l}0.613^{* *} \\
(2.37)\end{array}$ & $\begin{array}{l}0.614^{* *} \\
(2.37)\end{array}$ & $\begin{array}{l}0.412^{* *} \\
(2.25)\end{array}$ & $\begin{array}{l}0.484^{* *} \\
(2.50)\end{array}$ \\
\hline Cohort 1 & & $\begin{array}{r}0.168 \\
(0.32)\end{array}$ & & $\begin{array}{r}0.139 \\
(0.64)\end{array}$ \\
\hline Cohort 2 & & $\begin{array}{r}0.299 \\
(0.68)\end{array}$ & & $\begin{array}{l}-0.039 \\
(-0.24)\end{array}$ \\
\hline $\mathrm{R}^{2}$ & 0.068 & 0.068 & 0.126 & 0.132 \\
\hline $\mathrm{N}$ & 1,163 & 1,163 & 1,163 & 1,163 \\
\hline \multicolumn{5}{|c|}{${ }^{* *}$ means statistically significant at $5 \%$ level. } \\
\hline \multicolumn{5}{|c|}{$F E=$ fixed effects. } \\
\hline \multicolumn{5}{|c|}{$\begin{array}{l}\text { Notes: Outcome is log of monthly income. Figures in parentheses are t-statistics based on clustered standard errors. Cross-sectional } \\
\text { estimation is based on the } 2018 \text { round of the survey. Regressions include additional control variables at individual level (age and age } \\
\text { squared); household level (head's age, sex, and education; number of adult males and females; log of agricultural land); and village } \\
\text { level (village infrastructure such as primary and secondary schools, paved roads, electricity, government and nongovernment food } \\
\text { programs, prices of consumer goods). }\end{array}$} \\
\hline \multicolumn{5}{|c|}{$\begin{array}{l}\text { Sources: Bangladesh Institute of Development Studies-World Bank. 1992. Bangladesh Household Survey Data, 1991/92. Dhaka; } \\
\text { Bangladesh Institute of Development Studies-World Bank. 1999. Bangladesh Household Survey Data, 1998/99. Dhaka; Institute } \\
\text { for Inclusive Finance and Development and World Bank. 2011. Bangladesh Household Survey Data, 2010/11. Washington, DC; } \\
\text { and University of Tokyo Graduate School of Public Policy. 2018. Bangladesh Household Survey Data, 2018. Tokyo. }\end{array}$} \\
\hline
\end{tabular}

43 See the recent findings on the returns to education for the developing countries in Peet, Fink, and Fawzi (2015). In this research of 61 developing countries using the World Bank's living standards and measurement surveys over 1985-2012, findings suggest that average return to schooling is $7.6 \%$. Our estimate of $9 \%$ is therefore consistent with findings from developing countries. 


\section{CONCLUSIONS}

85. Gender disparity in education in many developing countries is a major policy concern and has important implications for development goals and objectives. A rich body of literature shows that female education is critical for human development (education, health, and other outcomes) and, therefore, has an important catalytic role in enhancing growth and development. Moreover, the observed differential in female education relative to male education is the primary factor motivating policymakers to search for ways to reduce, if not completely eliminate, gender gaps in human development outcomes.

86. Among the policies to reduce the gender gap in education, it is subsidies to female secondary education through stipends and other forms of assistance that are considered a direct and observable way to incentivize parents to educate girls at that level where gender disparity is high and persistent. The perceived wisdom is that since educating girls at the secondary level is costly for parents in developing countries for different reasons (both social and economic), providing subsidies for girls through stipends would be a way to promote secondary education, thus reducing persistent gender gaps. Indeed, experience with female stipends in a few countries has actually supported this view.

87. In Bangladesh, where gender disparity in secondary schooling was remarkably high in the 1980s and early 1990s, the introduction of a female secondary stipend program in 1994, targeted only in rural areas (where gender disparity was wider than it was in urban areas), was a milestone policy instrument in the female education program. Indeed, the secondary data suggest that female secondary school enrollment, relative to boys, rose substantially following the introduction of FSSAP in 1994, and that girls' achievement even surpassed boys' achievement in secondary education during 2000-2017. This anecdotal evidence suggests that FSSAP played a critical role in enhancing female secondary education in Bangladesh, consistent with a recent study (Hahn et al. 2017), which shows that FSSAP has in fact increased female educational achievements as well as female labor force participation in the formal wage sector; and also had beneficial effects on female age of marriage, matrimonial matching, and fertility.

88. Although a few studies have carried out impact analysis of FSSAP in previous years (using the exogeneous age eligibility condition, for example as in the Hahn et al. study, using time-series cross-sectional data analysis), the findings remained somewhat inconsistent for a number of reasons. First, availability of a stipend program does not guarantee girls' participation in secondary school; so individual ability matters, as do persistent household and community observed and unobserved characteristics that can affect how a female stipend program actually works in practice.

89. Second, eligibility by age may not be enforced as designed (meaning that every eligible girl attends secondary school because of a stipend program); therefore, program participation as opposed to program eligibility condition may matter more in assessing the effectiveness of the stipend program. However, program participation, as opposed to program eligibility, is endogenously determined by both individual, household, and community characteristics. The time-varying heterogeneity of program participation may matter more for the long-term outcomes, such as marital and spousal outcomes, including contraceptive use, fertility, and labor force participation. Such endogeneity issues must be resolved to estimate unbiased effects of FSSAP. 
90. The weaknesses of earlier impact evaluations of FSSAP prompted the use by the present study of longitudinal panel data covering 26 years (four rounds during 1991/92-2018). Policy issues were examined, namely, whether FSSAP matters; how much it matters; and in what way it does matter to both observed short-term and long-term outcomes associated with female education. More specifically, this paper analyzes an FSSAP intervention using individual-level data on female education and other related outcomes before and after the intervention against outcomes with and without the intervention (difference-in-differences). The paper exploits the exogenous age-specific eligibility condition, which provides a natural experiment to estimate the consistent estimates of the program benefits.

91. The first approach used is an individual-level fixed effects model that controls for the unobserved time-invariant individual, household, and community factors. The estimates of the average impact of the FSSAP program using the intent-to-treat model showed that the program matters for female education by increasing both enrollment, grade attainment, and secondary completion of girls. However, estimates of average impacts are found to be higher than those of Hahn et al. (2017), a finding consistent with our a priori expectations.

92. The average effects of FSSAP are also positive for female self-employment (23-25 percentage points) and nonfarm employment (49-73 percentage points) among employed women, age at marriage (1.4-2.2 years), and contraceptive use (15-31 percentage points). Consequently, there was a negative effect on fertility (reduction of 0.45 ) depending on the cohorts. ${ }^{44}$ Estimated impacts are even stronger when we endogenize program participation, as opposed to using exogenous age-specific program eligibility conditions, and hence, exogenous program participation. The instruments of age-cohort eligibility used in the participation decision are found appropriate for consistent impact estimates of FSSAP participation.

93. Thus, our consistent estimates of FSSAP intervention as per the FE-IV model show that FSSAP program participation of a girl increases her schooling on average by more than 3 years, and secondary school completion by over 5 percentage points. An additional year's exposure to FSSAP adds almost a year to total years of girls' schooling, and 2 percentage points to girls' secondary school completion rate.

94. Also illuminating is that the boys benefit as well from female stipends, because of income transfers accrued to families who receive such transfers for girls' enrollment. More importantly, the FSSAP is found to affect social outcomes such as age at marriage, female's self- and nonfarm employment, spouses' education, labor force participation status, and above all, contraceptive use and fertility.

95. What do these findings mean to policy making? It is cost-effective to educate girls at the secondary level through a stipend program introduced by the government. For example, completion of one grade (one year of education) costs the government $\$ 35$ per student. That 1-year stipend or support yields 1 year of additional education at the secondary level for each girl enrolled at the secondary level. This means that to support 2 million girls each year, the government should spend

\footnotetext{
44 We have considered a total of 18 outcomes; thus, the number of false rejections of null hypothesis (incorrectly finding statistical significance) could be high based on multiple hypothesis testing. One caveat of this study is it does not control such false rejections, resulting in a compromise on the efficiency of the estimates. That said, efficiency loss may not be substantial as the outcomes may not all be completely independent-they can be grouped into a few categories, and within each category certain outcomes may be related. For example, within the category of reproductive behavior, two outcomes, contraceptive use and total fertility, may be related. Similarly, grade completion and secondary completion may be related within the category of educational outcomes.
} 
$\$ 70$ million - for a yield of 2 million years' worth of education. Each year of secondary education implies an increase of $\$ 110$ in future income. ${ }^{45}$ Thus, the benefit-cost ratio is 3.14 , meaning benefits outweigh the social cost by over $200 \%$.

96. Since the calculated return to education takes into account income effects only, the total benefits of education must be even higher. This is because an increase in female education also enhances women's self- and nonfarm employment among employed, delays age at marriage, and increases contraceptive use, which in turn reduces fertility. This means that a stipend program has far-reaching effects on society; therefore, it is worth supporting. Interestingly, the female stipend is found to reduce the preference for sons, unlike the norms in many developing countries, and contrary to expectation, increases the preference for daughters. A female stipend program thus can change social behaviors persistent in societies such as those in Bangladesh. This finding, for the first time in the literature, is attributed to female education.

97. In the years shortly before COVID-19, gender disparity in secondary enrollment in Bangladesh had disappeared and girls have indeed fared better than boys in secondary school, so the female secondary stipend program targeted to girls (even in rural areas) may not be justified anymore. Instead, government support has been directed toward supporting school-level interventions, such as enhancing quality of teachers and teaching materials for raising the overall quality of secondary education. This is perhaps essential to helping students pass the secondary school certificate examination, so as to raise the secondary school completion rates, as well as the overall school grade attainment rates.

98. Government support may also be directed toward poor students-girls and boys alike-to help maintain higher school attainment overall. These policies are certainly a step toward raising both the quantity and quality of education. ${ }^{46}$ Enhancement programs on school quality, and support in teaching materials and teaching quality, have already been introduced to enhance the overall quality of education (both secondary school completion rates and overall grade attainments). The recent program design of the Government of Bangladesh for a "harmonized" stipend program at the secondary level is a targeted program to reach the poor, and is a partial policy formulation in the right direction.

99. The FSSAP program can be designed to address the gender-specific fallout during the ongoing COVID-19 crisis. Like other sectors, the pandemic has hurt Bangladesh's education system. Education is likely to be affected in two major ways. First, the systemic lockdown has shut down educational institutions nationwide, forcing all classroom exercises to go online or be broadcast through TV. The issue is that the educational institutions are not all well equipped to properly conduct online classes, especially a good number in rural areas, which do not have the necessary infrastructure. More importantly, a large share of rural households do not have access to the internet or have a television set. ${ }^{47}$ Thus, the coverage of these ad hoc measures is indeed limited. Second, the economic crisis as a fallout of COVID-19 may lead to school dropouts when schools open since education expenses may no longer be affordable to many impoverished families. Given the gender disparity in household

45 This is based on a 10\% social return to per capita income for each year of completed education, as suggested for low-to middle-income countries in Asia in a few well-known studies (Psacharopoulos and Patrinos 2004, Psacharopoulos 1994), and estimated annual per capita annual expenditure of Bangladesh in 2015 (PPRC 2016). Psacharopoulous and Patrinos (2018) also find nearly a 10\% private return to female education.

46 Quality of education is crudely measured here as the percentage of students who have completed secondary school (i.e., passed grade 10 examination); as well as the overall grade attainments (i.e., years of schooling attained). As shown by the household-level statistics, both measures are lower in Bangladesh compared to the cumulative school enrollment rates.

47 According to a recent study, $44 \%$ of the children aged 5-11 in rural areas have a television set at home, and only $3 \%$ of the rural households have a computer (Alamgir 2020). 
resource allocation, it goes without saying that girls are going to be disproportionately affected by the crisis. For many girls at the secondary level, dropouts may mean leaving the school system permanently and getting married away, a consequence that FSSAP and other incentive programs are meant to stop.

100. Bangladesh's current efforts to protect education must address the likely attrition of the girls, especially in rural areas. The measures already taken by the government include providing special stipends to students for 3 months and launching of an Education Unit Platform to provide students with free educational services over toll-free telephone calls. In addition, with support from the United Nations Educational, Scientific and Cultural Organization, the government is developing a project to conduct educational activities through radios. Moreover, a recovery plan for education is being designed. The plan should ensure that the benefits accrued through FSSAP are sustained. More specifically, some additional incentives must be built into the recovery package to prevent dropouts and expand the coverage of the learning activities through internet, TV, or other media during the lockdown. When the lockdown is relaxed or over, government should open up educational institutions by strictly following World Health Organization guidelines on social distancing and other measures. 


\section{APPENDIX: EVOLUTION OF THE FEMALE SECONDARY STIPEND AND ASSISTANCE PROGRAM}

1. This appendix summarizes the historical evolution of the Female Secondary Stipend and Assistance Program (FSSAP) into four different phases: (i) 1982-1994, (ii) 1994-2008, (iii) 2008-2018, and (iv) 2018-2023.

2. The FSSAP has evolved over time on many fronts while keeping its three core eligibility criteria of school attendance, minimum level of marks in examinations, and delaying of marriage. For instance, the target of the stipend program has been gradually shifted from gender to poverty as gender equity in access to education improves in Bangladesh. The stipend disbursement process used to be direct cash payment, but currently enables the use of bank accounts, including mobile banking. A number of projects inherited stipend programs during the last 3 decades.

\section{2-1994}

3. The female stipend program dates back to 1982 when the United States Agency for International Development started a small-scale cash transfer program for girls. After that, the Norwegian Agency for Development Cooperation funded a stipend program in 1987 in one upazila (a geographical region or unit in Bangladesh) through individual nongovernment organizations. This stipend program was expanded by one upazila every year, eventually covering six upazilas by 1992. In 1990, female access to education up to grade 8 was opened up in rural areas, and there was a need to encourage female school enrollments (Raynor and Wesson 2006). However, the amount of the stipend in fiscal year 1993 was determined without seriously studying the actual cost of secondary schooling, and an arbitrarily determined stipend amount was provided as an incentive for the girls' families.

\section{4-2008}

4. Built on the success in these pilot interventions, the Government of Bangladesh launched the FSSAP in 1993 with the support of the World Bank, covering 59 upazilas that had been substantiated from 1994. The initial plan was to continue the FSSAP for 5 years, and all girls in rural areas at secondary schools were eligible to receive a monthly stipend of 25 taka (Tk) in grade 6 up to Tk60 in grade 10. The females could also receive new books in grade 9 and exam fees in grade 10 (Raynor and Wesson 2006).

5. The FSSAP was further scaled up as the Nationwide Female Secondary Stipend Program in all rural upazilas through four different projects: (i) the Female Secondary School Assistance Project funded by the Government of Bangladesh and the World Bank, (ii) the Female Secondary Stipend Project funded by the government, (iii) the Secondary Education Development Project funded by the government and the Asian Development Bank (ADB), and (iv) the Female Education Stipend Project funded by the Government of Bangladesh and Norwegian Agency for Development Cooperation. The Nationwide Female Secondary Stipend Program was considered quite successful in increasing access to education for female secondary students. However, female enrollment outperforming male enrollment, and a lack of focus on the poor, were pointed out as challenges. 


\section{8-2018}

6. Against this backdrop, the government launched pro-poor stipend programs from 2008. The stipend programs aimed to provide equitable access and increase retention of secondary school students (grade 6-12) from poor households. The stipend programs were provided through four different projects that do not overlap with each other by upazila or grade: (i) the Secondary Education Sector Investment Program funded by the Government of Bangladesh and ADB, (ii) the Secondary Education Quality and Access Enhancement Project funded by the government and the World Bank, (iii) the Secondary Education Stipend Project funded by the government, and (iv) the Higher Secondary Stipend Project funded by the Government of Bangladesh. Both male and female secondary students were included in all the projects, and approximately $30 \%$ of enrolled secondary students were covered in total.

7. Each project has its own targeting mechanism, eligibility criteria, selection process, and stipend disbursement process, but the targeting mechanism was a key difference. The Secondary Education Quality and Access Enhancement Project (250 upazilas) used proxy means testing administered by upazila engineers of the Local Government Engineering Department. Another three projects used poverty-targeted criteria through a school-based committee. Proxy means testing has stronger integrity, because this is a household-based targeting mechanism that generates a score for applicants based on a set of observable characteristics. The poverty-targeted criteria use predetermined criteria but put more weight on human judgment. This enables identification of poor students based on local knowledge while leaving the chances of misuse of funds. The Secondary Education Sector Investment Program, Secondary Education Stipend Project, and the Higher Secondary Stipend Project differ slightly in gender targeting because the coverage is 20\% male and 30\% female (53 upazilas) for the Secondary Education Sector Investment Program; 10\% male and 30\% female (183 upazilas) for the Secondary Education Stipend Project; and is 10\% male and 40\% female (483 upazilas) for the Higher Secondary Stipend Project.

8. Qualitative interviews with stakeholders suggested that the stipend was particularly effective in improving school retention by reducing dropouts. Also, stipend recipients largely confirmed that this stipend contributed to delaying marriage. However, many stakeholders pointed out that the amount of the stipend program, around $\$ 20-\$ 40$ (Table A1.1), was far from enough to cover schooling expenses, and the amount was not increased despite inflation.

\section{8-2023}

9. The ADB-funded Secondary Education Sector Investment Program road map identifies the need to establish a single harmonized stipend program for the poor, and from 2018, the Harmonized Stipend Program was introduced. This blended proxy means testing with poverty targeting criteria by engaging head teachers and an upazila secondary education officer, to verify the proxy means testing information. The gender preference was not included because females were no longer behind males on access to secondary education.

Before the Secondary Education Sector Investment Program, ADB also supported a stipend program through Secondary Education Sector Improvement (1999-2006) and Secondary Education Sector Development Program (2006-2013). 
Table A1.1: Rates of Various Stipend Programs, 2017

(Taka)

\begin{tabular}{|c|c|c|c|c|c|c|c|c|}
\hline \multirow[b]{2}{*}{ Grade } & \multicolumn{4}{|c|}{$\begin{array}{c}\text { SESIP } \\
\text { (54 Upazilas) }\end{array}$} & \multicolumn{4}{|c|}{$\begin{array}{c}\text { SESP } \\
\text { (183 Upazilas) }\end{array}$} \\
\hline & $\begin{array}{l}\text { Stipend } \\
\text { (month) }\end{array}$ & $\begin{array}{l}\text { Tuition } \\
\text { (month) }\end{array}$ & $\begin{array}{c}\text { Exam Fees } \\
\text { (year) }\end{array}$ & $\begin{array}{l}\text { Total } \\
\text { (year) }\end{array}$ & $\begin{array}{l}\text { Stipend } \\
\text { (month) }\end{array}$ & $\begin{array}{l}\text { Tuition } \\
\text { (month) }\end{array}$ & $\begin{array}{c}\text { Exam Fees } \\
\text { (year) }\end{array}$ & $\begin{array}{l}\text { Total } \\
\text { (year) }\end{array}$ \\
\hline 6 & 100 & 15 & & 1,380 & 100 & 15 & & 1,380 \\
\hline 7 & 100 & 15 & & 1,380 & 100 & 15 & & 1,380 \\
\hline 8 & 125 & 15 & & 1,680 & 120 & 15 & & 1,620 \\
\hline 9 & 210 & 20 & & 2,760 & 150 & 20 & & 2,040 \\
\hline \multirow[t]{2}{*}{10} & 210 & 20 & 750 & 3,510 & 150 & 20 & 750 & 2,790 \\
\hline & \multicolumn{4}{|c|}{$\begin{array}{c}\text { SEQAEP } \\
(250 \text { Upazilas) }\end{array}$} & & & & \\
\hline Grade & $\begin{array}{l}\text { Stipend } \\
\text { (month) }\end{array}$ & $\begin{array}{l}\text { Tuition } \\
\text { (month) }\end{array}$ & $\begin{array}{c}\text { Exam Fees } \\
\text { (year) }\end{array}$ & $\begin{array}{l}\text { Total } \\
\text { (year) }\end{array}$ & & & & \\
\hline 6 & 100 & 15 & & 1,380 & & & & \\
\hline 7 & 125 & 15 & & 1,680 & & & & \\
\hline 8 & 160 & 15 & & 2,100 & & & & \\
\hline 9 & 180 & 20 & & 2,400 & & & & \\
\hline \multirow[t]{2}{*}{10} & 200 & 20 & 750 & 3,390 & & & & \\
\hline & \multicolumn{5}{|c|}{$\begin{array}{c}\text { HSSP } \\
\text { (483 Upazilas) }\end{array}$} & & & \\
\hline Grade & $\begin{array}{l}\text { Stipend } \\
\text { (month) }\end{array}$ & $\begin{array}{l}\text { Tuition } \\
\text { (month) }\end{array}$ & $\begin{array}{l}\text { Books } \\
\text { (year) }\end{array}$ & $\begin{array}{c}\text { Exam Fees } \\
\text { (year) }\end{array}$ & $\begin{array}{l}\text { Total } \\
\text { (year) }\end{array}$ & & & \\
\hline 11-Science & 175 & 50 & 700 & & 3,400 & & & \\
\hline 11- Others & 125 & 50 & 600 & & 2,700 & & & \\
\hline 12-Science & 175 & 50 & & 900 & 3,600 & & & \\
\hline 12-Others & 125 & 50 & & 600 & 2,700 & & & \\
\hline
\end{tabular}

HSSP = Higher Secondary Stipend Project, SESIP = Secondary Education Sector Investment Program, SEQAEP = Secondary Education Quality and Access Enhancement Project, SESP = Secondary Education Stipend Project.

Note: SEQAEP and SESP have separate benefits, such as awards and additional stipends for class 10.

Source: Ministry of Education. 2017. Comprehensive Comparative Review of the Bangladesh Secondary Education Stipend Projects/ Program. Dhaka. 


\section{Table A1.2: Female Secondary Stipend and Assistance Program-} Salient Characteristics of the Target Sample

(ages 0-20 in 1991/92)

\begin{tabular}{|c|c|}
\hline Category & Numbers \\
\hline \multicolumn{2}{|l|}{ Division } \\
\hline Barisal & 180 \\
\hline Chittagong & 133 \\
\hline Dhaka & 802 \\
\hline Khulna & 603 \\
\hline Mymensingh & 214 \\
\hline Rajshahi & 235 \\
\hline Rangpur & 517 \\
\hline Sylhet & 196 \\
\hline Total & 2,880 \\
\hline \multicolumn{2}{|l|}{ Distribution by Sex } \\
\hline Girls & 1,163 \\
\hline Boys & 1,717 \\
\hline Share of FSSAP-eligible among all girls (\%) & 75.7 \\
\hline \multicolumn{2}{|c|}{ Share of FSSAP-Participants among All Girls (\%) } \\
\hline $1991 / 92$ & 0 \\
\hline 1998/99 & 21.7 \\
\hline 2010/11 & 36.2 \\
\hline 2018 & 36.2 \\
\hline \multicolumn{2}{|c|}{ Duration of FSSAP Exposure among Participants (years) } \\
\hline $1991 / 92$ & 0 \\
\hline $1998 / 99$ & 2.6 \\
\hline 2010/11 & 3.5 \\
\hline 2018 & 3.5 \\
\hline
\end{tabular}

FSSAP = Female Secondary Stipend and Assistance Program.

Sources: Bangladesh Institute of Development Studies-World Bank. 1992. Bangladesh Household Survey Data, 1991/92. Dhaka; Bangladesh Institute of Development Studies-World Bank. 1999. Bangladesh Household Survey Data, 1998/99. Dhaka; Institute for Inclusive Finance and Development and World Bank. 2011. Bangladesh Household Survey Data, 2010/11. Washington, DC; and University of Tokyo Graduate School of Public Policy. 2018. Bangladesh Household Survey Data, 2018. Tokyo. 
Table A1.3: Female Secondary Stipend and Assistance Program-Baseline Characteristics of Individual Attrition

\begin{tabular}{lccc}
\hline Variables & $\begin{array}{c}\text { Attrited } \\
\text { Individuals } \\
\text { (left) }\end{array}$ & $\begin{array}{c}\text { Individuals Who } \\
\text { Stayed Over } \\
\text { Rounds }\end{array}$ & $\begin{array}{c}\text { Difference } \\
\text { (t-statistics) }\end{array}$ \\
\hline Household-Level Variables & & & \\
\hline Sex of household head (male=1, female=0) & 0.981 & 0.978 & 0.36 \\
\hline Age of household head (years) & 45.771 & 44.459 & 1.80 \\
\hline Grade completed by household head (years) & 2.952 & 3.015 & -0.27 \\
\hline Number of adult males in household & 2.018 & 1.997 & 0.26 \\
\hline Number of adult females in household & 1.726 & 1.805 & -1.16 \\
\hline Log of household agricultural land (decimals) & 3.749 & 3.930 & -1.58 \\
\hline Village-Level Variables & & & 1.50 \\
\hline Village has primary schools & 0.697 & 0.652 & -0.37 \\
\hline Village has secondary schools & 0.192 & 0.201 & -0.03 \\
\hline Village has commercial banks & 0.084 & 0.085 & -0.05 \\
\hline Village has government food programs & 0.100 & 0.101 & -1.90 \\
\hline Village has nongovernment food programs & 0.110 & 0.153 & 2.01 \\
\hline Village is accessible throughout the year & 0.981 & 0.955 & 2.15 \\
\hline Village has electricity & 0.593 & 0.524 & \\
\hline$N$ & $N=3,139$ & & \\
\hline
\end{tabular}

Sources: Bangladesh Institute of Development Studies-World Bank. 1992. Bangladesh Household Survey Data, 1991/92. Dhaka; Bangladesh Institute of Development Studies-World Bank. 1999. Bangladesh Household Survey Data, 1998/99. Dhaka; Institute for Inclusive Finance and Development and World Bank. 2011. Bangladesh Household Survey Data, 2010/11. Washington, DC; and University of Tokyo Graduate School of Public Policy. 2018. Bangladesh Household Survey Data, 2018. Tokyo.

\section{Table A1.4: Female Secondary Stipend and Assistance Program-Baseline Determinants of Individual Attrition}

(probit estimates)

\begin{tabular}{lcc}
\hline Variables & Marginal Effects & t-statistics \\
\hline Household-Level Variables & & -0.02 \\
\hline Sex of household head (male=1, female=0) & -0.001 & 1.37 \\
\hline Age of household head (years) & 0.001 & 0.41 \\
\hline Grade completed by household head (years) & 0.001 & 0.41 \\
\hline Number of adult males in household & 0.004 & -1.21 \\
\hline Number of adult females in household & -0.010 & -1.08 \\
\hline Log of household agricultural land (decimals) & -0.005 & 0.84 \\
\hline Village-Level Variables & & -0.10 \\
\hline Village has secondary schools & 0.013 & -0.18 \\
\hline Village has commercial banks & -0.002 & -0.005 \\
\hline
\end{tabular}


Table A1.4 continued

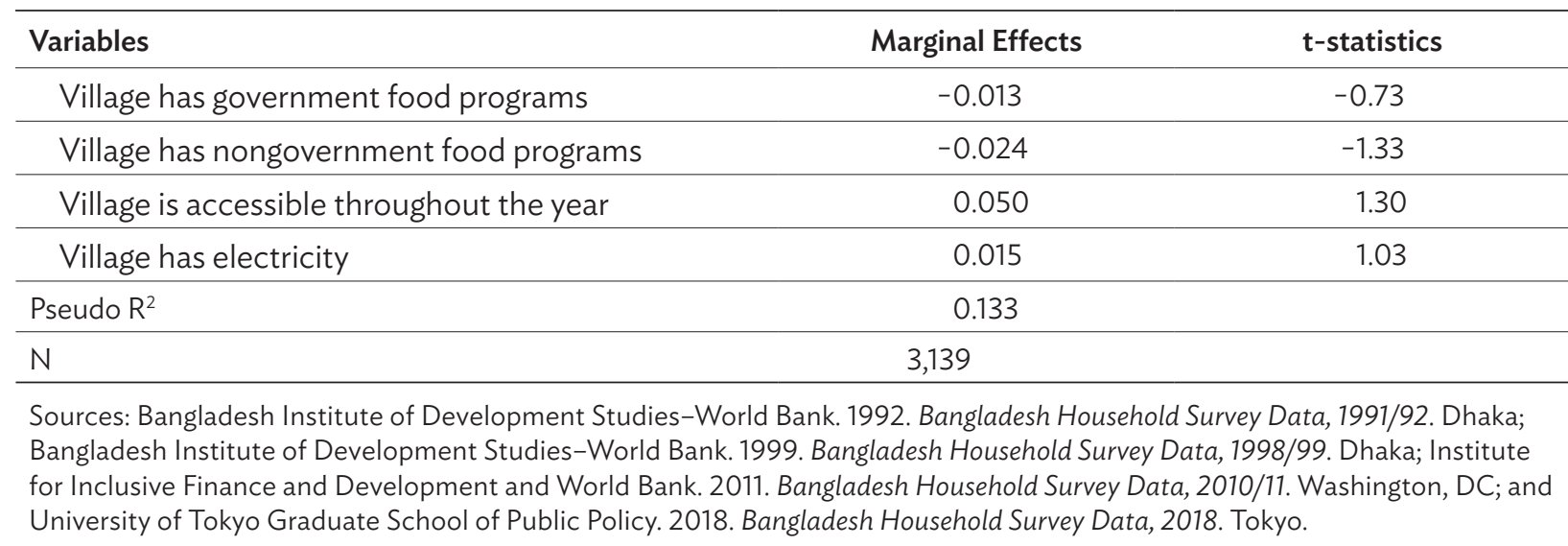

\section{Table A1.5: Female Secondary Stipend and Assistance Program-Baseline Characteristics by FSSAP Eligibility}

\begin{tabular}{|c|c|c|c|}
\hline Variables & Eligible Girls & Ineligible Girls & $\begin{array}{l}\mathrm{t} \text {-statistics of the } \\
\text { Difference }\end{array}$ \\
\hline \multicolumn{4}{|l|}{ Household-Level Variables } \\
\hline Sex of household head $($ male $=1$, female $=0$ ) & 0.981 & 0.988 & -0.83 \\
\hline Age of household head (years) & 42.370 & 47.730 & -6.67 \\
\hline Grade completed by household head (years) & 2.797 & 2.854 & -0.24 \\
\hline Number of adult males in household & 1.774 & 2.370 & -7.32 \\
\hline Number of adult females in household & 1.668 & 2.380 & -9.72 \\
\hline Log of household agricultural land (decimals) & 3.746 & 4.370 & -5.10 \\
\hline \multicolumn{4}{|l|}{ Village-Level Variables } \\
\hline Village has primary schools & 0.691 & 0.590 & 3.14 \\
\hline Village has secondary schools & 0.212 & 0.160 & 1.91 \\
\hline Village has commercial banks & 0.093 & 0.085 & 0.39 \\
\hline Village has government food programs & 0.081 & 0.064 & 0.96 \\
\hline Village has nongovernment food programs & 0.161 & 0.137 & 0.97 \\
\hline Village is accessible throughout the year & 0.962 & 0.935 & 1.91 \\
\hline Village has electricity & 0.564 & 0.502 & 1.81 \\
\hline $\mathrm{N}$ & \multicolumn{3}{|l|}{$N=1,405$} \\
\hline \multicolumn{4}{|c|}{$\begin{array}{l}\text { Sources: Bangladesh Institute of Development Studies-World Bank. 1992. Bangladesh Household Survey Data, 1991/92. Dhaka; } \\
\text { Bangladesh Institute of Development Studies-World Bank. 1999. Bangladesh Household Survey Data, 1998/99. Dhaka; Institute } \\
\text { for Inclusive Finance and Development and World Bank. 2011. Bangladesh Household Survey Data, 2010/11. Washington, DC; and } \\
\text { University of Tokyo Graduate School of Public Policy. 2018. Bangladesh Household Survey Data, 2018. Tokyo. }\end{array}$} \\
\hline
\end{tabular}




\section{Table A1.6: Female Secondary Stipend and Assistance Program-Descriptive Statistics of Selected Explanatory Variables}

\begin{tabular}{lcc}
\hline Variables & Mean & Standard Deviation \\
\hline Household-Level Variables & & 0.251 \\
\hline Sex of household head (male=1, female=0) & 0.932 & 12.051 \\
\hline Age of household head (years) & 44.813 & 4.175 \\
\hline Grade completed by household head (years) & 3.726 & 1.069 \\
\hline Number of adult males in household & 1.759 & 1.073 \\
\hline Number of adult females in household & 1.817 & 376.722 \\
\hline Household agricultural land (decimals) & 137.706 & 0.432 \\
\hline Village-Level Variables & & 0.467 \\
\hline Village has primary schools & 0.753 & 0.314 \\
\hline Village has secondary schools & 0.320 & 0.496 \\
\hline Village has commercial banks & 0.111 & 0.392 \\
\hline Village has government food programs & 0.434 & 0.332 \\
\hline Village has nongovernment food programs & 0.190 & 0.443 \\
\hline Village is accessible throughout the year & 0.874 & 0.732 \\
\hline Village has electricity & $\mathrm{N}=4,652$ & \\
\hline N & & \\
\hline Sources: & & \\
\hline
\end{tabular}

Sources: Bangladesh Institute of Development Studies-World Bank. 1992. Bangladesh Household Survey Data, 1991/92. Dhaka; Bangladesh Institute of Development Studies-World Bank. 1999. Bangladesh Household Survey Data, 1998/99. Dhaka; Institute for Inclusive Finance and Development and World Bank. 2011. Bangladesh Household Survey Data, 2010/11. Washington, DC; and University of Tokyo Graduate School of Public Policy. 2018. Bangladesh Household Survey Data, 2018. Tokyo.

\section{Table A1.7: Female Secondary Stipend and Assistance Program-Descriptive Statistics of Women's Outcome Variables}

\begin{tabular}{|c|c|c|c|c|c|}
\hline Outcome Variables & $1991 / 92$ & 1998/99 & $2010 / 11$ & 2018 & All Years \\
\hline \multicolumn{6}{|l|}{ Education Outcomes } \\
\hline \multicolumn{6}{|l|}{ Ever enrolled } \\
\hline Girls & $\begin{array}{c}0.409 \\
(0.492)\end{array}$ & $\begin{array}{c}0.839 \\
(0.367)\end{array}$ & $\begin{array}{r}0.892 \\
(0.311)\end{array}$ & $\begin{array}{r}0.892 \\
(0.311) \\
\end{array}$ & $\begin{array}{c}0.758 \\
(0.428)\end{array}$ \\
\hline Boys & $\begin{array}{c}0.506 \\
(0.500)\end{array}$ & $\begin{array}{r}0.846 \\
(0.361)\end{array}$ & $\begin{array}{c}0.906 \\
(0.292)\end{array}$ & $\begin{array}{c}0.908 \\
(0.289)\end{array}$ & $\begin{array}{c}0.792 \\
(0.406)\end{array}$ \\
\hline \multicolumn{6}{|c|}{ Grade completed (years) } \\
\hline Girls & $\begin{array}{c}0.866 \\
(2.046)\end{array}$ & $\begin{array}{c}3.280 \\
(3.334)\end{array}$ & $\begin{array}{c}6.341 \\
(4.027)\end{array}$ & $\begin{array}{c}6.596 \\
(4.420)\end{array}$ & $\begin{array}{c}4.270 \\
(4.281)\end{array}$ \\
\hline Boys & $\begin{array}{c}1.415 \\
(2.453)\end{array}$ & $\begin{array}{c}3.760 \\
(3.552)\end{array}$ & $\begin{array}{r}6.478 \\
(4.197) \\
\end{array}$ & $\begin{array}{c}6.963 \\
(4.752) \\
\end{array}$ & $\begin{array}{c}4.654 \\
(4.437) \\
\end{array}$ \\
\hline \multicolumn{6}{|c|}{ Completed secondary level } \\
\hline Girls & $\begin{array}{c}0.012 \\
(0.107) \\
\end{array}$ & $\begin{array}{c}0.043 \\
(0.203)\end{array}$ & $\begin{array}{c}0.217 \\
(0.412)\end{array}$ & $\begin{array}{c}0.236 \\
(0.425) \\
\end{array}$ & $\begin{array}{c}0.127 \\
(0.333)\end{array}$ \\
\hline Boys & $\begin{array}{c}0.011 \\
(0.104)\end{array}$ & $\begin{array}{c}0.077 \\
(0.267)\end{array}$ & $\begin{array}{c}0.259 \\
(0.438)\end{array}$ & $\begin{array}{c}0.276 \\
(0.447)\end{array}$ & $\begin{array}{c}0.156 \\
(0.363)\end{array}$ \\
\hline
\end{tabular}


Table A1.7 continued

\begin{tabular}{|c|c|c|c|c|c|}
\hline Outcome Variables & 1991/92 & 1998/99 & 2010/11 & 2018 & All Years \\
\hline \multicolumn{6}{|c|}{ Women's Employment and Husband's Outcomes } \\
\hline Women's labor force participation & - & $\begin{array}{c}0.0004 \\
(0.019)\end{array}$ & $\begin{array}{c}0.052 \\
(0.223)\end{array}$ & $\begin{array}{c}0.122 \\
(0.327)\end{array}$ & $\begin{array}{c}0.044 \\
(0.2014)\end{array}$ \\
\hline Woman is self-employed & - & $\begin{array}{c}0.0004 \\
(0.019)\end{array}$ & $\begin{array}{c}0.008 \\
(0.089)\end{array}$ & $\begin{array}{r}0.035 \\
(0.183)\end{array}$ & $\begin{array}{c}0.011 \\
(0.103)\end{array}$ \\
\hline Woman is employed in nonfarm sector & - & $\begin{array}{c}0.0004 \\
(0.019)\end{array}$ & $\begin{array}{c}0.051 \\
(0.220)\end{array}$ & $\begin{array}{c}0.119 \\
(0.324)\end{array}$ & $\begin{array}{c}0.043 \\
(0.202) \\
\end{array}$ \\
\hline Husband's grade attainment (years) & - & $\begin{array}{c}0.531 \\
(2.128)\end{array}$ & $\begin{array}{r}5.090 \\
(4.923)\end{array}$ & $\begin{array}{c}6.512 \\
(4.925)\end{array}$ & $\begin{array}{c}5.002 \\
(5.032)\end{array}$ \\
\hline Husband's labor force participation & - & $\begin{array}{c}0.226 \\
(0.419) \\
\end{array}$ & $\begin{array}{c}0.804 \\
(0.397)\end{array}$ & $\begin{array}{r}0.990 \\
(0.101) \\
\end{array}$ & $\begin{array}{c}0.788 \\
(0.409)\end{array}$ \\
\hline Husband is self-employed & - & $\begin{array}{c}0.094 \\
(0.292)\end{array}$ & $\begin{array}{c}0.436 \\
(0.496)\end{array}$ & $\begin{array}{c}0.539 \\
(0.499) \\
\end{array}$ & $\begin{array}{c}0.425 \\
(0.494)\end{array}$ \\
\hline Husband is employed in nonfarm sector & - & $\begin{array}{c}0.122 \\
(0.328)\end{array}$ & $\begin{array}{c}0.605 \\
(0.489)\end{array}$ & $\begin{array}{c}0.742 \\
(0.437)\end{array}$ & $\begin{array}{c}0.587 \\
(0.492)\end{array}$ \\
\hline \multicolumn{6}{|c|}{ Women's Marriage and Fertility-Related Outcomes } \\
\hline Women's age at marriage (years) & $\begin{array}{c}15.582 \\
(1.557) \\
\end{array}$ & $\begin{array}{l}16.229 \\
(2.363)\end{array}$ & $\begin{array}{l}17.788 \\
(2.935)\end{array}$ & $\begin{array}{l}18.512 \\
(3.727)\end{array}$ & $\begin{array}{l}17.842 \\
(3.326)\end{array}$ \\
\hline Currently use contraceptives & - & $\begin{array}{c}0.009 \\
(0.094)\end{array}$ & $\begin{array}{c}0.637 \\
(0.481)\end{array}$ & $\begin{array}{c}0.667 \\
(0.472) \\
\end{array}$ & $\begin{array}{c}0.441 \\
(0.497)\end{array}$ \\
\hline Total fertility & - & - & $\begin{array}{c}1.520 \\
(0.949)\end{array}$ & $\begin{array}{c}2.084 \\
(0.974)\end{array}$ & $\begin{array}{c}1.824 \\
(1.003)\end{array}$ \\
\hline Desired number of sons & $\begin{array}{c}1.836 \\
(0.524) \\
\end{array}$ & $\begin{array}{c}1.372 \\
(0.558) \\
\end{array}$ & $\begin{array}{c}1.103 \\
(0.313) \\
\end{array}$ & $\begin{array}{c}1.066 \\
(0.272) \\
\end{array}$ & $\begin{array}{c}1.083 \\
(0.293) \\
\end{array}$ \\
\hline Desired number of daughters & $\begin{array}{c}0.557 \\
(0.561)\end{array}$ & $\begin{array}{c}0.515 \\
(0.541)\end{array}$ & $\begin{array}{c}0.554 \\
(0.559)\end{array}$ & $\begin{array}{r}0.608 \\
(0.531)\end{array}$ & $\begin{array}{c}0.566 \\
(0.548)\end{array}$ \\
\hline
\end{tabular}

- means data not available.

Note: Figures in parentheses are standard deviations.

Sources: Bangladesh Institute of Development Studies-World Bank. 1992. Bangladesh Household Survey Data, 1991/92. Dhaka; Bangladesh Institute of Development Studies-World Bank. 1999. Bangladesh Household Survey Data, 1998/99. Dhaka; Institute for Inclusive Finance and Development and World Bank. 2011. Bangladesh Household Survey Data, 2010/11. Washington, DC; and University of Tokyo Graduate School of Public Policy. 2018. Bangladesh Household Survey Data, 2018. Tokyo. 


\section{Table A1.8: Female Secondary Stipend and Assistance Program-Effects on Girls' Education Outcomes, Using a Third Cohort, Randomly Selected from the Control Group, as an Additional Regressor}

\begin{tabular}{lccc}
\hline Outcomes & Ever Enrolled & Grade Completed (years) & Completed Secondary Level \\
\hline Cohort 1 & $0.430^{* *}$ & $2.734^{* *}$ & 0.018 \\
\cline { 2 - 4 } & $(13.49)$ & $(8.75)$ & $(0.55)$ \\
\hline Cohort 2 & 0.058 & $2.142^{* *}$ & 0.031 \\
\hline Cohort 3 & $(1.30)$ & $(5.36)$ & $(0.79)$ \\
\hline $\mathrm{N}$ & 0.008 & 0.450 & -0.014 \\
\hline
\end{tabular}

** means statistically significant at $5 \%$ level.

Note: Figures in parentheses are t-statistics based on clustered standard errors. Regressions control for year fixed-effects, and include additional control variables at household level (head's age, sex and education; number of adult males and females; log of agricultural land); and village level (village infrastructure such as primary and secondary schools, paved roads, electricity, government and nongovernment food programs, and prices of consumer goods).

Sources: Bangladesh Institute of Development Studies-World Bank. 1992. Bangladesh Household Survey Data, 1991/92. Dhaka; Bangladesh Institute of Development Studies-World Bank. 1999. Bangladesh Household Survey Data, 1998/99. Dhaka; Institute for Inclusive Finance and Development and World Bank. 2011. Bangladesh Household Survey Data, 2010/11. Washington, DC; and University of Tokyo Graduate School of Public Policy. 2018. Bangladesh Household Survey Data, 2018. Tokyo. 


\section{Table A1.9: Female Secondary Stipend and Assistance Program-First Stage Regression Output for Estimation: Determinants of Girls' Participation}

\begin{tabular}{|c|c|}
\hline Variables & Estimates \\
\hline \multicolumn{2}{|l|}{ Excluded Instrument } \\
\hline \multirow[t]{2}{*}{ Girl is eligible to participate in FSSAP (in cohort 1) } & $0.164^{* *}$ \\
\hline & $(6.75)$ \\
\hline \multirow[t]{2}{*}{ Girl is eligible to participate in FSSAP (in cohort 2) } & $0.230^{* *}$ \\
\hline & $(5.07)$ \\
\hline \multicolumn{2}{|l|}{ Included Instruments (control variables) } \\
\hline \multirow[t]{2}{*}{ Sex of household head (male $=1$, female $=0$ ) } & -0.015 \\
\hline & $(-0.48)$ \\
\hline \multirow[t]{2}{*}{ Age of household head (years) } & 0.001 \\
\hline & $(1.37)$ \\
\hline \multirow[t]{2}{*}{ Grade completed by household head (years) } & $0.009^{* *}$ \\
\hline & $(3.78)$ \\
\hline \multirow[t]{2}{*}{ Number of adult males in household } & -0.007 \\
\hline & $(-0.73)$ \\
\hline \multirow[t]{2}{*}{ Number of adult females in household } & 0.014 \\
\hline & $(1.01)$ \\
\hline \multirow[t]{2}{*}{ Log of household agricultural land (decimals) } & $0.011^{* *}$ \\
\hline & $(2.02)$ \\
\hline \multirow[t]{2}{*}{ Village has primary schools } & -0.031 \\
\hline & $(-1.35)$ \\
\hline \multirow[t]{2}{*}{ Village has secondary schools } & -0.014 \\
\hline & $(-0.69)$ \\
\hline \multirow[t]{2}{*}{ Village has commercial banks } & 0.006 \\
\hline & $(0.27)$ \\
\hline \multirow[t]{2}{*}{ Village has government food programs } & -0.007 \\
\hline & $(-0.35)$ \\
\hline \multirow[t]{2}{*}{ Village has nongovernment food programs } & $0.029^{*}$ \\
\hline & $(1.68)$ \\
\hline \multirow[t]{2}{*}{ Village is accessible throughout the year } & 0.014 \\
\hline & $(0.62)$ \\
\hline \multirow[t]{2}{*}{ Village has electricity } & 0.025 \\
\hline & $(0.81)$ \\
\hline $\mathrm{R}^{2}$ & 0.342 \\
\hline $\mathrm{N}$ & 4,652 \\
\hline
\end{tabular}

** means statistically significant at $5 \%$ level.

FSSAP = Female Secondary Stipend and Assistance Program

Note: Figures in parentheses are t-statistics based on clustered standard errors at the village level. Regressions additionally include price of consumer goods.

Sources: Bangladesh Institute of Development Studies-World Bank. 1992. Bangladesh Household Survey Data, 1991/92. Dhaka; Bangladesh Institute of Development Studies-World Bank. 1999. Bangladesh Household Survey Data, 1998/99. Dhaka; Institute for Inclusive Finance and Development and World Bank. 2011. Bangladesh Household Survey Data, 2010/11. Washington, DC; and University of Tokyo Graduate School of Public Policy. 2018. Bangladesh Household Survey Data, 2018. Tokyo. 


\section{REFERENCES}

Afridi, F. 2010. The Impact of School Meals on School Participation: Evidence from Rural India. Journal of Development Studies. 47 (11). pp. 1636-1656.

Ahmed, A. U. and C. del Ninno. 2002. Food for Education Program in Bangladesh: An Evaluation of Its Impact on Educational Attainment and Food Security. Discussion Paper. No. 138. Washington, DC: International Food Policy Research Institute.

Akhter, H. and E. Haque. 2014. The Role of Son Preference on Modern Contraceptive Use in Bangladesh. Journal of Humanities and Social Science. 9 (7). pp. 89-96.

Alamgir, M. 2020. Distance Learning During Pandemic: Digital Divide Leaves Many Behind. The Daily Star. 5 July. https://www.thedailystar.net/frontpage/news/distance-learning-duringpandemic-digital-divide-leaves-many-behind-1925205.

Alderman, H. Et al. 2000. Attrition in Longitudinal Household Survey Data: Some Tests for Three Developing-Country Samples. Policy Research Working Paper. No. 2447. Washington, DC: The World Bank.

Arulampalam, W., A. L. Booth, and M. P. Taylor. 2000. Unemployment Persistence. Oxford Economic Papers. 52 (1). pp. 24-50.

Asian Development Bank (ADB). 2006. Report and Recommendation of the President to the Board of Directors: Proposed Sector Development Program Loans People's Republic of Bangladesh: Secondary Education Sector Development Program. Manila.

- 2015. Key Indicators for Asia and the Pacific 2015: Special Chapter on a Smarter Future-Skills, Education and Growth in Asia. Manila.

Baird, S. et al. 2013. Relative Effectiveness of Conditional and Unconditional Cash Transfers for Schooling Outcomes in Developing Countries. Campbell Collaboration Systematic Reviews. https://doi.org/10.4073/csr.2013.8

Bangladesh Bureau of Education Information and Statistics (BANBEIS). 2018. Bangladesh Education Statistics, 2017. Dhaka.

Bangladesh Bureau of Statistics (BBS). 2012. Bangladesh Population and Housing Census, 2011. Dhaka.

__. 1998. Bangladesh Statistical Yearbook of Bangladesh, 1998. Dhaka.

Bangladesh Institute of Development Studies-World Bank. 1992. Bangladesh Household Survey Data, 1991/92. Dhaka.

—_. 1999. Bangladesh Household Survey Data, 1998/99. Dhaka.

Black, S. E., P. J. Devereux, and K. G. Salvanes. 2008. Staying in the Classroom and Out of The Maternity Ward? The Effect of Compulsory Schooling Laws on Teenage Births. Economic Journal. 118 (530). pp. 1025-54. 
Breierova, L. and E. Duflo. 2004. The Impact of Education on Fertility and Child Mortality: Do Fathers Really Matter Less Than Mothers? NBER Working Paper. No. 10513. Cambridge, MA: National Bureau of Economic Research.

Chamberlain, G. 1984. Panel Data. In Z. Griliches, M. D. Intriligator, eds. Handbook of Econometrics. Amsterdam: North-Holland.

Chaudhury, N. and D. Parajuli. 2010. Conditional Cash Transfers and Female Schooling: The Impact of the Female School Stipend Programme on Public School Enrollments in Punjab, Pakistan. Applied Economics. 42 (28). pp. 3565-3583.

Currie, J. and E. Moretti. 2003. Mother's Education and the Intergenerational Transmission of Human Capital: Evidence from College Openings. Quarterly Journal of Economics. 118 (4). pp. 1495-532.

Filmer, D. and N. Schady. 2011. Does More Cash in Conditional Cash Transfer Programs Always Lead to Larger Impacts on School Attendance? Journal of Development Economics. 96 (1). pp. 150-57.

Fitzgerald, J., P. Gottschalk, and R. Mofitt. 1998. An Analysis of Sample Attrition in Panel Data. Journal of Human Resources. 33 (2). pp. 251-299.

Giannini, S. and A. Albrectsen. 2020. Covid-19 School Closures around the World Will Hit Girls Hardest. UNESCO. https://en.unesco.org/news/covid-19-school-closures-around-world-will-hit-girlshardest.

Hahn, Y. et al. 2017. Education, Marriage, and Fertility: Long-Term Evidence from a Female Stipend Program in Bangladesh. Economic Development and Cultural Change. 66 (2). pp. 381-415.

Hayashi, R. and N. Matsuda. 2020. COVID-19 Impact on Job Postings: Real-Time Assessment Using Bangladesh and Sri Lanka Online Job Portals. ADB Briefs. No. 135. Manila: ADB.

Heath, R. and A. M. Mobarak. 2015. Manufacturing Growth and the Lives of Bangladeshi Women. Journal of Development Economics. 115. pp. 1-15.

Heckman, J. J. 1981. The Incidental Parameters Problem and the Problem of Initial Conditions in Estimating a Discrete Time-Discrete Data Stochastic Process. In C. Manski and D. McFadden, eds., Structural Analysis of Discrete Data with Econometric Applications. Cambridge, MA: MIT Press.

Herz, B. et al. 1991. Letting Girls Learn: Promising Approaches in Primary and Secondary Education. World Bank Discussion Papers. No. 133. Washington, DC: World Bank.

Institute for Inclusive Finance and Development and World Bank. 2011. Bangladesh Household Survey Data, 2010/11. Washington, DC.

Kabeer, N. 2012. Missing Women in Bangladesh. In 50.50. Gender, Sexuality, and Social Justice. 7 (November).

Khandker, S., M. Pitt, and N. Fuwa. 2003. Subsidy to Promote Girls' Secondary Education: The Female Stipend Program in Bangladesh. Washington, DC: World Bank. 
Kim, J., H. Alderman, and P. Orazem. 1999. Can Private School Subsidies Increase Enrollment for the Poor? The Quetta Urban Fellowship Program. World Bank Economic Review. 13 (3). pp. 443-65.

King, E. and A. M. Hill, eds. 1993. Women's Education in Developing Countries: Barriers, Benefits, and Policies. Baltimore, MD: Johns Hopkins University Press.

King, E., P. Orazem, and D. Wohlgemuth. 1999. Central Mandates and Local Incentives: The Colombia Education Voucher Program. World Bank Economic Review. 13 (3). pp. 467-91.

Liang, X. 1996. Bangladesh: Female Secondary School Assistance. Washington, DC: World Bank.

Mannan, M. A. 1988. Preference for Son, Desire for Additional Children and Contraceptive Use in Bangladesh. Bangladesh Development Studies. 16 (September). pp. 31-55.

Park, C. and A. M. Inocencio. 2020. COVID-19 is No Excuse to Regress on Gender Equality. ADB Briefs. No. 157. Manila: ADB.

Peet, E., G. Fink, and W. Fawzi, 2015. Returns to Education in Developing Countries: Evidence from the Living Standards Measurement Study. Economics of Education Review. 49. pp. 69-90.

Power and Participation Research Center (PPRC). 2016. Bangladesh 2016: Politics, Governance and Middle Income Aspirations-An Empirical Study. Dhaka: Power and Population Research Center.

Psacharopoulos, G. 1994. Return to Investment in Education: A Global Update. World Development. 22 (9). pp. 1325-1343.

Psacharopoulos, G. and H. A. Patrinos. 2004. Return to Investment in Education: A Further Update. Education Economics. 12 (2). pp. 111-134.

-2018. Returns to Investment in Education: A Decennial Review of the Global Literature. Education Economics. 26 (5). pp. 445-458.

Ravallion, M. and Q. Wodon. 2001. Does Child Labour Displace Schooling? Evidence on Behavioural Responses to an Enrollment Subsidy. Economic Journal. 110 (462). C158-75.

Raynor, J. and K. Wesson. 2006 The Girls' Stipend Program in Bangladesh. Journal of Education for International Development. 2 (2). 1-12.

Schultz, P. T. 1987. Education Investments and Returns in Economic Development. Discussion Paper. No. 528. New Haven, CT: Economic Growth Center, Yale University.

Schurmann, A. T. 2009. Review of the Bangladesh Female Secondary School Stipend Project Using a Social Exclusion Framework. Journal of Health Population and Nutrition. 27 (4). 505-17.

Shamsuddin, M. 2015. Labour Market Effects of a Female Stipend Programme in Bangladesh. Oxford Development Studies. 43 (4). 1636-165.

Strauss, J. and D. Thomas. 1995. Empirical Modeling of Household and Family Decisions. In J. Strauss and D. Thomas, eds. Handbook of Development Economics. 3, Part 1. Amsterdam: Elsevier. Thomas, D., E. Frankenberg, and J. P. Smith. 2001. Lost but Not Forgotten: Attrition and Follow-up in the Indonesian Family Life Survey. Journal of Human Resources. 36 (3). pp. 556-592. 
United Nations Educational, Scientific and Cultural Organization (UNESCO). 2020. UNESCO COVID-19 Education Response. How Many Students Are at Risk of Not Returning to School? Paris.

University of Tokyo Graduate School of Public Policy. 2018. Bangladesh Household Survey Data, 2018. Tokyo.

World Bank. 1997. Bangladesh Female Secondary School Assistance Project: Mid-term Review. Washington, DC.

—. 2000. World Development Report 2000/2001. New York: Oxford University Press.

_. 2017. Economic Impacts of Child Marriage: Global Synthesis Brief. Washington, DC.

- Contraceptive Prevalence, Any Methods (\% of women ages 15-49) - Bangladesh. https://data. worldbank.org/indicator/SP.DYN.CONU.ZS?locations=BD (accessed 1 July 2020).

—. Data Catalog. https://datacatalog.worldbank.org/search?query=\%20mean-age-first-marriagefemale (accessed 20 July 2020).

—. Literacy Rate, Adult Male (\% of males ages 15 and above) - Bangladesh. https://data.worldbank.org/indicator/SE.ADT.LITR.FE.ZS?locations=BD (accessed 31 July 2020).

—. School Enrollment, Secondary, Male (\% net). https://data.worldbank.org/indicator/SE.SEC. NENR.FE?locations=BD (accessed 31 July 2020).

Xu, S., A. S. Shonchoy, and T. Fujii. 2019. Illusion of Gender Parity in Education: Intrahousehold Resource Allocation in Bangladesh. ADBI Working Paper. 1004. Tokyo: Asian Development Bank Institute.

Ziliak, J. P. and T. J. Kniesner. 1998. The Importance of Sample Attrition in Life Cycle Labor Supply Estimation. Journal of Human Resources. 33 (2). pp. 507-530. 


\section{The Female Secondary Stipend and Assistance Program in Bangladesh}

What Did It Accomplish?

Are stipends for girls in the secondary level worth supporting to enhance socioeconomic and demographic changes? This paper examines the impact of the Female Secondary Stipend and Assistance Program (FSSAP) in Bangladesh in terms of observed short- and long- term outcomes associated with female education. How did FSSAP impact the education of girls, and of boys if it also did? The paper also explores the impact of the subsidy on female labor force participation, as well as age at marriage, fertility, and other effects on society.

\section{About the Asian Development Bank}

ADB is committed to achieving a prosperous, inclusive, resilient, and sustainable Asia and the Pacific, while sustaining its efforts to eradicate extreme poverty. Established in 1966, it is owned by 68 members -49 from the region. Its main instruments for helping its developing member countries are policy dialogue, loans, equity investments, guarantees, grants, and technical assistance. 